Published in final edited form as:

Inorg Chem. 2006 November 13; 45(23): 9197-9205. doi:10.1021/ic061554r.

\title{
Synthesis of [(HIPTNCH $\left.\left.{ }_{2} \mathrm{CH}_{2}\right)_{3} \mathrm{~N}\right] \mathrm{V}$ Compounds (HIPT = 3,5-(2,4,6-i- $\left.\mathrm{Pr}_{3} \mathrm{C}_{6} \mathrm{H}_{2}\right)_{2} \mathrm{C}_{6} \mathrm{H}_{3}$ ) and an Evaluation of Vanadium for the Reduction of Dinitrogen to Ammonia
}

\author{
Nathan C. Smythe, Richard R. Schrock, Peter Müller, and Walter W. Weare \\ Department of Chemistry, Massachusetts Institute of Technology, Cambridge, Massachusetts \\ 02139
}

\begin{abstract}
Green $\left[\mathrm{HIPTN}{ }_{3} \mathrm{~N}\right] \mathrm{V}(\mathrm{THF})\left(\left[\mathrm{HIPTN}{ }_{3} \mathrm{~N}\right]^{3-}=\left[\left(\mathrm{HIPTNCH}_{2} \mathrm{CH}_{2}\right)_{3} \mathrm{~N}\right]^{3-}\right.$ where HIPT $=3,5-(2,4,6-\mathrm{i}-$ $\left.\mathrm{Pr}_{3} \mathrm{C}_{6} \mathrm{H}_{2}\right)_{2} \mathrm{C}_{6} \mathrm{H}_{3}$ ) can be prepared in $70-80 \%$ yield through addition of $\mathrm{H}_{3}\left[\mathrm{HIPTN}_{3} \mathrm{~N}\right]$ to $\mathrm{VCl}_{3}(\mathrm{THF})_{3}$ in THF followed by addition of $\mathrm{LiN}\left(\mathrm{SiMe}_{3}\right)_{2}$. From $\left[\mathrm{HIPTN}{ }_{3} \mathrm{~N}\right] \mathrm{V}(\mathrm{THF})$ the following have been prepared: $\left\{\left[\mathrm{HIPTN}_{3} \mathrm{~N}\right] \mathrm{VN}_{2}\right\} \mathrm{K},\left[\mathrm{HIPTN}{ }_{3} \mathrm{~N}\right] \mathrm{V}\left(\mathrm{NH}_{3}\right)$, [HIPTN $\left.{ }_{3} \mathrm{~N}\right] \mathrm{V}=\mathrm{NH},\left[\mathrm{HIPTN}_{3} \mathrm{~N}\right]$ $\mathrm{V}=\mathrm{NSiMe}_{3},\left[\mathrm{HIPTN} \mathrm{N}_{3} \mathrm{~N}\right] \mathrm{V}=\mathrm{O}$, $\left[\mathrm{HIPTN}_{3} \mathrm{~N}\right] \mathrm{V}=\mathrm{S}$, and $\left[\mathrm{HIPTN}_{3} \mathrm{~N}\right] \mathrm{V}(\mathrm{CO})$. No ammonia is formed from dinitrogen using $\left\{\left[\mathrm{HIPTN} \mathrm{N}_{3} \mathrm{~N}\right] \mathrm{VN}_{2}\right\} \mathrm{K}$, [HIPTN $\left.{ }_{3} \mathrm{~N}\right] \mathrm{V}=\mathrm{NH}$, or $\left[\mathrm{HIPTN} \mathrm{N}_{3} \mathrm{~N}\right] \mathrm{V}\left(\mathrm{NH}_{3}\right)$ as the initial species under conditions that were successful in the analogous [HIPTN $\left.{ }_{3} \mathrm{~N}\right]$ Mo system. X-ray structural studies are reported for $\left[\mathrm{HIPTN}{ }_{3} \mathrm{~N}\right] \mathrm{V}(\mathrm{THF})$ and $\left[\mathrm{HIPTN}_{3} \mathrm{~N}\right] \mathrm{V}\left(\mathrm{NH}_{3}\right)$.
\end{abstract}

\section{INTRODUCTION}

We have been exploring early transition metal complexes that contain a triamidoamine ligand $\left(\left[\left(\mathrm{RNCH}_{2} \mathrm{CH}_{2}\right)_{3} \mathrm{~N}\right]^{3-}\right) .{ }^{1}$ In the last several years we have been interested primarily in Mo complexes that contain the [ $\left.\left(\mathrm{HIPTNCH}_{2} \mathrm{CH}_{2}\right)_{3} \mathrm{~N}\right]^{3-}$ ligand, where HIPT $=3,5-(2,4,6-\mathrm{i}-$ $\left.\mathrm{Pr}_{3} \mathrm{C}_{6} \mathrm{H}_{2}\right)_{2} \mathrm{C}_{6} \mathrm{H}_{3}=$ HexaIsoPropylTerphenyl), 2 since various [ $\left.\left(\mathrm{HIPTNCH}_{2} \mathrm{CH}_{2}\right)_{3} \mathrm{~N}\right] \mathrm{Mo}$ complexes have been found to serve as catalysts for the catalytic reduction of dinitrogen to ammonia at room temperature and pressure with protons and electrons. ${ }^{3}$ The $\left[\left(\mathrm{HIPTNCH} \mathrm{CH}_{2}\right)_{3} \mathrm{~N}\right]^{3-}$ ligand $\left(\left[\mathrm{HIPTN}{ }_{3} \mathrm{~N}\right]^{3-}\right.$ ) was designed to prevent formation of relatively stable and unreactive $\mu$-dinitrogen complexes, maximize steric protection of a monometallic metal coordination site, and provide increased solubility of complexes in nonpolar solvents relative to triamidoamine complexes that contain unsubstituted terphenyl groups. Examples of Mo species that serve as catalysts and that are believed to lie on the catalytic pathway to ammonia include $\left[\mathrm{HIPTN}_{3} \mathrm{~N}\right] \mathrm{MoN}_{2}$, [HIPTN $\left.{ }_{3} \mathrm{~N}\right] \mathrm{Mo}-\mathrm{N}=\mathrm{N}-\mathrm{H}$, $\left[\mathrm{HIPTN}{ }_{3} \mathrm{~N}\right] \mathrm{Mo} \equiv \mathrm{N}$, and $\left[\mathrm{HIPTN}_{3} \mathrm{~N}\right] \mathrm{Mo}\left(\mathrm{NH}_{3}\right)$. We have shown that $\left[\mathrm{HIPTN}_{3} \mathrm{~N}\right] \mathrm{W}$ analogs of many of the $\left[\mathrm{HIPTN} \mathrm{N}_{3} \mathrm{~N}\right]$ Mo species can be prepared, but none serves as a catalyst for the reduction of dinitrogen catalytically under conditions analogous to those employed for reduction with Mo catalysts. ${ }^{4}$ Among the problems associated with the tungsten system is the apparent instability of [HIPTN $\left.{ }_{3} \mathrm{~N}\right] \mathrm{W}\left(\mathrm{NH}_{3}\right)$, the analog of $\left[\mathrm{HIPTN}_{3} \mathrm{~N}\right] \mathrm{Mo}\left(\mathrm{NH}_{3}\right)$. [ $\left.\mathrm{HIPTN}_{3} \mathrm{~N}\right]$ $\mathrm{Mo}\left(\mathrm{NH}_{3}\right)$ is of central importance in the catalytic reduction of dinitrogen by [HIPTN $\left.{ }_{3} \mathrm{~N}\right] \mathrm{Mo}$ complexes since the step in which ammonia is replaced by dinitrogen "restarts" the catalytic cycle. We also have explored [HIPTN $\left.{ }_{3} \mathrm{~N}\right] \mathrm{Cr}$ species, which are not catalysts for the catalytic reduction of dinitrogen, primarily, it is believed, because dinitrogen does not bind to $\left[\mathrm{HIPTN}_{3} \mathrm{~N}\right] \mathrm{Cr} .{ }^{5}$

In addition to the relatively well-studied Mo-Fe nitrogenase, ${ }^{6} \mathrm{~V}$-Fe and $\mathrm{Fe}-\mathrm{Fe}$ nitrogenases are known. ${ }^{7}$ These variants are formed when molybdenum (V-Fe) or molybdenum and vanadium $(\mathrm{Fe}-\mathrm{Fe})$ are not available. Unlike the Mo-Fe nitrogenase, ${ }^{8} \mathrm{~V}-\mathrm{Fe}$ and $\mathrm{Fe}-\mathrm{Fe}$ 
nitrogenases have not been structurally characterized. The simplest proposal is that the V-Fe and Fe-Fe nitrogenases adopt the same core structure as the Mo-Fe nitrogenase with vanadium or iron in place of molybdenum. Since the efficiency of forming ammonia selectively from dinitrogen by these enzymes appears to follow the order Mo-Fe $>\mathrm{V}-\mathrm{Fe}>\mathrm{Fe}-\mathrm{Fe}$ (from most to least efficient), we felt that a vanadium-catalyzed reduction of dinitrogen might be demonstrable.

A number of vanadium dinitrogen complexes are known. The most common oxidation states of $\mathrm{V}$ in dinitrogen complexes are $\mathrm{V}(3+),{ }^{9} \mathrm{~V}(2+),{ }^{10}$ and $\mathrm{V}(-1){ }^{11}$. Only in the $\mathrm{V}(-1)$ species, which have the formulae $\left[\mathrm{L}_{4} \mathrm{~V}\left(\mathrm{~N}_{2}\right)_{2}\right]^{-}$where $\mathrm{L}$ is a phosphine or $\mathrm{L}_{2}$ is a bisphosphine, is dinitrogen bound end-on with $v_{\mathrm{NN}}=1706 \mathrm{~cm}^{-1}$ to $1833 \mathrm{~cm}^{-1}$; all others are bimetallic species that contain a $\mu-\mathrm{N}_{2}$ ligand. The $\left[\mathrm{L}_{4} \mathrm{~V}\left(\mathrm{~N}_{2}\right)_{2}\right]^{-}$complexes are isoelectronic with the Chatt-type neutral $\mathrm{Mo}(0)$ and $\mathrm{W}(0) \mathrm{d}^{6}$ complexes with the same stoichiometry. ${ }^{12}$ The $\mathrm{V}(3+)$ complexes are analogous to niobium and tantalum complexes that contain what has been described as a $\mathrm{N}_{2}{ }^{4-}$ ligand, 13 i.e., the two $\mathrm{V}(3+)$ metals could reduce dinitrogen by up to four electrons.

There may be a special stability associated with such " $\mathrm{d}^{0}$ " $(\mathrm{M}=\mathrm{N}-\mathrm{N}=\mathrm{M})$ species that contain a $\mathrm{N}_{2}{ }^{4-}$ bridging ligand, perhaps even for $\mathrm{V}$, which one would expect to be the least reducing of the $\mathrm{d}^{2}$ metals in Group 5 .

Vanadium complexes have been reported that contain the triamidoamine ligands $\left[\mathrm{MeN}_{3} \mathrm{~N}\right]^{3-}, 14\left[\mathrm{C}_{6} \mathrm{~F}_{5} \mathrm{~N}_{3} \mathrm{~N}\right]^{3-}, 15\left[\mathrm{Me}_{3} \mathrm{SiN}_{3} \mathrm{~N}\right]^{3-}, 16$ and $\left[t-\mathrm{BuMe}_{2} \mathrm{SiN}_{3} \mathrm{~N}\right]^{3-,}, 17$ but none of the chemistry explored with these species focused on dinitrogen chemistry per se. For $\left[\mathrm{C}_{6} \mathrm{~F}_{5} \mathrm{~N}_{3} \mathrm{~N}\right]$ $\mathrm{V},\left[\mathrm{Me}_{3} \mathrm{SiN}_{3} \mathrm{~N}\right] \mathrm{V}$, and $\left[t-\mathrm{BuMe}_{2} \mathrm{SiN}_{3} \mathrm{~N}\right] \mathrm{V}$ no evidence for coordination of dinitrogen, either end-on or bridging, was obtained. However, $\left[\mathrm{C}_{6} \mathrm{~F}_{5} \mathrm{~N}_{3} \mathrm{~N}\right] \mathrm{V},\left[\mathrm{Me}_{3} \mathrm{SiN}_{3} \mathrm{~N}\right] \mathrm{V}$, and $[t-$

$\left.\mathrm{BuMe}_{2} \mathrm{SiN}_{3} \mathrm{~N}\right] \mathrm{V}$ complexes bind some $\sigma$ donors (e.g., THF or acetonitrile), and several $\mathrm{V}(5+)$ species have been prepared that contain $\left[\mathrm{C}_{6} \mathrm{~F}_{5} \mathrm{~N}_{3} \mathrm{~N}\right]^{3-}$ and $\left[\mathrm{Me}_{3} \mathrm{SiN}_{3} \mathrm{~N}\right]^{3-}$ ligands (e.g., $\mathrm{V}=\mathrm{NH}$, $\mathrm{V}=\mathrm{NSiMe}_{3}$, and $\mathrm{V}=\mathrm{O}$ species). Failure to form an end-on $\mathrm{V}(3+)$ dinitrogen complex may not be surprising since the only known end-on $\mathrm{V}$ dinitrogen complexes contain $\mathrm{V}(-1)$ (vide supra), where backbonding to a single dinitrogen is significant. It should be noted, however, that even these $\left[\mathrm{L}_{4} \mathrm{~V}\left(\mathrm{~N}_{2}\right)_{2}\right]^{-}$species lose dinitrogen in vacuo. ${ }^{11}$ Cleavage of dinitrogen by a (presumably bimetallic) vanadium complex that contains the $\left[\mathrm{Me}_{3} \mathrm{SiN}\right.$ $\left.\left(\mathrm{CH}_{2} \mathrm{CH}_{2} \mathrm{NSiMe}_{3}\right)_{2}\right]^{2-}$ ligand has been reported to give a $\mathrm{V}_{2}(\mu-\mathrm{N})_{2}$ species. ${ }^{18}$

In $\left[\mathrm{HIPTN}_{3} \mathrm{~N}\right]^{3-}$ species, $\mu$-dinitrogen complexes cannot form for steric reasons. A plausible mechanism for reduction of dinitrogen by [HIPTN $\left.{ }_{3} \mathrm{~N}\right] \mathrm{V}$ species is shown in Scheme 1. It is interesting to note that $\left\{\left[\mathrm{HIPTN}_{3} \mathrm{~N}\right] \mathrm{Mo}\right\}^{+}(\mathrm{d} 2)$, which is isoelectronic with $\left[\mathrm{HIPTN}_{3} \mathrm{~N}\right] \mathrm{V}$, only relatively weakly binds dinitrogen, as judged by the fact that $v_{\mathrm{NN}}=2255 \mathrm{~cm}^{-1}$ and ${ }^{15} \mathrm{~N}_{2}$ for exchanges for $\mathrm{N}_{2}$ over a period of minutes at room temperature. $3 \mathrm{~d}$ The likely lower $\mathrm{V}-\mathrm{N}_{2}$ bond strength in $\left[\mathrm{HIPTN}{ }_{3} \mathrm{~N}\right] \mathrm{V}\left(\mathrm{N}_{2}\right)$ versus the Mo- $\mathrm{N}_{2}$ bond strength in $\left[\mathrm{HIPTN}_{3} \mathrm{~N}\right] \mathrm{Mo}\left(\mathrm{N}_{2}\right)$ would appear to make [HIPTN $\left.{ }_{3} \mathrm{~N}\right] \mathrm{V}\left(\mathrm{N}_{2}\right)$ unlikely. However, $\left\{\left[\mathrm{HIPTN}_{3} \mathrm{~N}\right] \mathrm{V}\right\}^{-}$is isoelectronic with $\left[\mathrm{HIPTN}_{3} \mathrm{~N}\right] \mathrm{Mo}$, which readily binds dinitrogen $\left(v_{\mathrm{NN}}=1990 \mathrm{~cm}^{-1}\right)$. Therefore $\left\{\left[\mathrm{HIPTN}_{3} \mathrm{~N}\right] \mathrm{V}\right.$ $\left.\left(\mathrm{N}_{2}\right)\right]^{-}$may be viable from [HIPTN $\left.{ }_{3} \mathrm{~N}\right] \mathrm{V}$ in the presence of the appropriate reducing agent, or $\left[\mathrm{HIPTN}{ }_{3} \mathrm{~N}\right] \mathrm{V}-\mathrm{N}=\mathrm{NH}$ may be formed from $\left[\mathrm{HIPTN}_{3} \mathrm{~N}\right] \mathrm{V}$ in the presence of the appropriate reducing agent and a proton source under dinitrogen. In this paper we report the synthesis of $\left[\mathrm{HIPTN}_{3} \mathrm{~N}\right] \mathrm{V}$ compounds, including $\left\{\left[\mathrm{HIPTN}_{3} \mathrm{~N}\right] \mathrm{V}\left(\mathrm{N}_{2}\right)\right]^{-}$, along with some preliminary studies concerned with the catalytic reduction of dinitrogen.

\section{RESULTS AND DISCUSSION}

\section{Synthesis and structure of [HIPTN $\left.{ }_{3} \mathrm{~N}\right] \mathrm{V}$ (THF)}

A violet solution is formed upon mixing $\mathrm{H}_{3}\left[\mathrm{HIPTN}_{3} \mathrm{~N}\right]$ with $\mathrm{VCl}_{3}(\mathrm{THF})_{3}$ in THF. The violet solution turns dark green upon addition of $\mathrm{LiN}\left(\mathrm{SiMe}_{3}\right)_{2}$. Green $\left[\mathrm{HIPTN}_{3} \mathrm{~N}\right] \mathrm{V}(\mathrm{THF})(\mathrm{V}(\mathrm{THF})$ where $\mathbf{V}=\left[\mathrm{HIPTN}_{3} \mathrm{~N}\right] \mathrm{V}$ ) can be isolated from this solution and recrystallized from pentane at 
low temperature $\left(c a .-35^{\circ} \mathrm{C}\right)$ in good overall yield (70-80\%). Freshly isolated $\mathbf{V}(\mathrm{THF})$ is a bright lime green, but the color darkens to an army green as solvent of crystallization is lost. The lime green color returns upon dissolution in pentane or toluene. $\mathbf{V}(\mathrm{THF})$ is analogous to known $\left[\mathrm{C}_{6} \mathrm{~F}_{5} \mathrm{~N}_{3} \mathrm{~N}\right] \mathrm{V}$ (THF). ${ }^{15 \mathrm{a}}$ Blue $\left[\mathrm{Me}_{3} \mathrm{SiN}_{3} \mathrm{~N}\right] \mathrm{V}^{16 \mathrm{~b}}$ turns green upon the addition of substrates such as $\mathrm{MeCN}$, but it apparently does not bind THF strongly enough to yield $\left[\mathrm{Me}_{3} \mathrm{SiN}_{3} \mathrm{~N}\right] \mathrm{V}$ (THF). V(THF) tends to crystallize as flakes, but a crystal suitable for single crystal x-ray diffraction was finally obtained from a heptane solution at room temperature by slowly concentrating the solution stepwise over a period of days.

An X-ray structural study of $\mathbf{V}$ (THF) (Tables 1 and 2, Figure 1) reveals it to be analogous to several complexes of this general type and virtually the same as the structure of $\left[\mathrm{C}_{6} \mathrm{~F}_{5} \mathrm{~N}_{3} \mathrm{~N}\right] \mathrm{V}$ (THF). ${ }^{15 a}$ For example, the five V-ligand bond lengths listed in Table 2 for $\mathbf{V}$ (THF) are similar to the corresponding values in $\left[\mathrm{C}_{6} \mathrm{~F}_{5} \mathrm{~N}_{3} \mathrm{~N}\right] \mathrm{V}$ (THF) (1.968(3), 1.958(3), 1.946(3), 2.132(3), and 2.152(3) A, respectively). In V(THF) the central ring of one of the HIPT groups is almost perpendicular $\left(81.0^{\circ}\right)$ to the plane that contains the amido nitrogen to which it is bound, while the other two are tilted $\sim 50^{\circ}$ from vertical. The amido planes of the amido ligands are tipped between $10^{\circ}$ and $20^{\circ}$ from the vertical, according to the $\mathrm{O}-\mathrm{V}-\mathrm{N}-\mathrm{C}_{\mathrm{ipso}}$ dihedral angles (Table 2). These dihedral angles are the largest of the two compounds reported here, simply, it is believed, because THF is sterically more demanding than ammonia. This finding is consistent with other structures in which the HIPT groups adopt a wide variety of orientations (in terms of rotation about the $\mathrm{N}^{-} \mathrm{C}_{\mathrm{ipso}}$ bond and "tipping" of the amido nitrogen plane from the vertical) in response to the steric demands of the ligand bound in the trigonal pocket. One of the most dramatic examples of the degree to which the ligand framework can accommodate a sterically demanding ligand in the apical pocket is the structure $\left\{\left[\mathrm{HIPTN}_{3} \mathrm{~N}\right] \mathrm{Mo}(2,6-\right.$

dimethylpyridine) $\}^{+, 3 \mathrm{e}}$ in which the 2,6-lutidine is bound "off-axis" to a significant degree $\left(\mathrm{N}_{\text {amine }}-\mathrm{Mo}-\mathrm{N}_{\text {lut }}=157^{\circ}\right)$ in a "slot" created by two of the HIPT groups. Such asymmetry is not detectable in room temperature NMR spectra since the HIPT groups are rotating and rearranging at a rate faster than the NMR time scale.

While V(THF) appears to be quite stable thermally at room temperature in an atmosphere of pure dinitrogen, it is extraordinarily sensitive to even traces of oxygen, with which it reacts irreversibly to give a purple compound. This oxygen sensitivity necessitates that the utmost precautions be taken to minimize exposure of open samples even to an inert atmosphere in a glovebox over some period of time. V(THF) is not stable at high temperatures, however. At $\sim 60{ }^{\circ} \mathrm{C}$ it starts to decompose to a black solid. The black solid is soluble, even in $\mathrm{Me}_{4} \mathrm{Si}$, but so far has not been obtained in the form of what we feel is a pure material. Therefore $\mathbf{V}$ (THF) was always dried in vacuo at room temperature. All attempts to obtain a THF free complex by heating the solid in vacuo led to decomposition. All reactions of $\mathbf{V}(\mathrm{THF})$ that are described beyond this point can be found in Scheme 2 .

\section{Synthesis of $\left\{\left[\mathrm{HIPTN} \mathrm{N}_{3} \mathrm{~N}_{\mathrm{VN}}\right\}^{-}\right.$}

Addition of potassium graphite or sodium naphthalenide to a solution of V(THF) in THF or DME under dinitrogen results in immediate formation of a bright red solution that contains salts of the $\left\{\left[\mathrm{HIPTN} \mathrm{N}_{3} \mathrm{~N}\right] \mathrm{VN}_{2}\right\}^{-}$anion. Potassium graphite is the preferred reductant since graphite is easily removed via filtration. The $\left\{\left[\mathrm{HIPTN}_{3} \mathrm{~N}\right] \mathrm{VN}_{2}\right\}^{-}$anion is extremely reactive, readily attacking Teflon. Growing single crystals of $\left\{\left[\mathrm{HIPTN}_{3} \mathrm{~N}\right] \mathrm{VN}_{2}\right\} \mathrm{K}$ suitable for and $\mathrm{X}$ ray study has proven difficult so far as a consequence of its ready oxidation. X-ray structures of related $\mathrm{Mo}^{3}$ and $\mathrm{W}^{4}$ species have been reported. $\left\{\left[\mathrm{HIPTN}_{3} \mathrm{~N}\right] \mathrm{VN}_{2}\right\}^{-}$may be viewed either as a dinitrogen complex of $\mathrm{V}(2+)$ or as a deprotonated hydrazido complex of $\mathrm{V}(4+)$, i.e., $\left\{\left[\mathrm{HIPTN}_{3} \mathrm{~N}\right] \mathrm{V}-\mathrm{N}=\mathrm{N}_{\beta}{ }^{-}\right.$, in which the negative charge is likely to be localized to a significant degree on $\mathrm{N}_{\beta}$. Delocalization of electron density throughout the V-N-N system makes an 
assignment of the metal's oxidation state difficult. A $\left\{\mathbf{V N}_{2}\right\}^{-}$salt is not observed upon addition of $\mathrm{CrCp}_{2}{ }_{2}$ or $\mathrm{CoCp}_{2}$ to a THF solution of $\mathbf{V}(\mathrm{THF})$.

IR spectra of THF or DME solutions of $\left\{\left[\mathrm{HIPTN}_{3} \mathrm{~N}\right] \mathrm{VN}_{2}\right\} \mathrm{K}$ reveal an absorption consistent with monomeric end-on dinitrogen $\left(v_{\mathrm{NN}}=1883 \mathrm{~cm}^{-1}, v 15_{\mathrm{N}} 15_{\mathrm{N}}=1821 \mathrm{~cm}^{-1}\right)$. The value of $1883 \mathrm{~cm}^{-1}$ is slightly higher than $v_{\mathrm{NN}}$ values in the highly reducing $\mathrm{V}(-1)$ species that have the formula $\left[\mathrm{L}_{4} \mathrm{~V}\left(\mathrm{~N}_{2}\right)_{2}\right]^{-}$where $v_{\mathrm{NN}}=1706 \mathrm{~cm}^{-1}$ to $1833 \mathrm{~cm}^{-1.11}$ To our knowledge $\left\{\left[\mathrm{HIPTN}_{3} \mathrm{~N}\right] \mathrm{VN}_{2}\right\} \mathrm{K}$ is the only end-on bound dinitrogen complex that is observable at room temperature other than the $\left[\mathrm{L}_{4} \mathrm{~V}\left(\mathrm{~N}_{2}\right)_{2}\right]^{-}$species. Interestingly, the IR spectrum of $\left\{\left[\mathrm{HIPTN}_{3} \mathrm{~N}\right] \mathrm{V}^{15} \mathrm{~N}_{2}\right\} \mathrm{K}$ reveals that $\sim 50 \%$ of the sample consists of $\left\{\left[\mathrm{HIPTN}_{3} \mathrm{~N}\right] \mathrm{VN}_{2}\right\} \mathrm{K}$ after the time it takes to filter and take and IR spectrum ( 10 minutes) under a natural $\mathrm{N}_{2}$ atmosphere (Figure 2). After one day only $\left\{\left[\mathrm{HIPTN}{ }_{3} \mathrm{~N}\right] \mathrm{VN}_{2}\right\} \mathrm{K}$ is present, further confirming the exchange of ${ }^{15} \mathrm{~N}_{2}$ with $\mathrm{N}_{2}$. The mechanism of this exchange reaction is not known. In the isoelectronic [HIPTN ${ }_{3} \mathrm{~N}$ ] MoN $\mathrm{N}_{2}$ species the exchange of ${ }^{15} \mathrm{~N}_{2}$ with $\mathrm{N}_{2}$ is first order in Mo and zero order in dinitrogen pressure (at least at $\sim 3$ atm overpressure) with $\mathrm{t}_{1 / 2} \sim 30 \mathrm{~h} .{ }^{3 \mathrm{~d}, \mathrm{f}}$ This result is consistent with slow unimolecular loss of dinitrogen to yield the "naked" [HIPTN ${ }_{3}$ N]Mo species followed by binding of free dinitrogen to yield [HIPTN $\left.{ }_{3} \mathrm{~N}\right] \mathrm{MoN}_{2}$. In contrast, replacement of THF with dinitrogen in [HIPTN $\left.{ }_{3} \mathrm{~N}\right] \mathrm{Mo}(\mathrm{THF})$ is complete in seconds. $3 \mathrm{~d}, \mathrm{f}$ The order of the reaction in which THF is replaced with dinitrogen has been proposed to be first order in dinitrogen. Therefore the theory has arisen that replacement of a $\sigma$ donor with a $\pi$ acceptor (or vice vers $a$ ) is fast relative to replacement of a $\pi$ acceptor with a $\pi$ acceptor. ${ }^{3 \mathrm{f}}$ In the latter circumstance replacement must proceed via the relatively high energy "naked" species, $\left[\mathrm{HIPTN}_{3} \mathrm{~N}\right] \mathrm{Mo}$.

In $\left\{\left[\mathrm{HIPTN}_{3} \mathrm{~N}\right] \mathrm{MoN}_{2}\right\} \mathrm{MgX}(\mathrm{THF})_{\mathrm{n}}$ species $\left(\mathrm{X}=\mathrm{Br}\right.$ or $\mathrm{Cl}$ and $\mathrm{n}$ is variable) $v_{\mathrm{NN}}$ values in IR spectra depend strongly upon the solvent and origin of the $\left\{\left[\mathrm{HIPTN}_{3} \mathrm{~N}\right] \mathrm{MoN}_{2}\right\} \mathrm{MgX}(\mathrm{THF})_{\mathrm{n}}$ sample as a consequence of different degrees of solvation of the magnesium ion versus interaction of magnesium with some part of the network of aryl rings. $3 \mathrm{~b}$ The highest values of $v_{\mathrm{NN}}$ are observed in $\left[\mathrm{Bu}_{4} \mathrm{~N}\right]\left\{\left[\mathrm{HIPTN}_{3} \mathrm{~N}\right] \mathrm{MoN}_{2}\right\}\left(v_{\mathrm{NN}}=1855 \mathrm{~cm}^{-1}\right.$ in benzene and 1859 $\mathrm{cm}^{-1}$ in THF) in which there is essentially no interaction of the counterion with the $\beta$ nitrogen in the diazenido ligand. ${ }^{3 \mathrm{~b}}$ In the IR spectrum of $\left\{\left[\mathrm{HIPTN}_{3} \mathrm{~N}\right] \mathrm{VN}_{2}\right\} \mathrm{K}$ in $\mathrm{C}_{6} \mathrm{D}_{6}$ no single strong stretch is observed. The $\mathrm{N}_{2}$ stretches in $\left\{\left[\mathrm{HIPTN}_{3} \mathrm{~N}\right] \mathrm{VN}_{2}\right\} \mathrm{K}$ in $\mathrm{C}_{6} \mathrm{D}_{6}$ are expected to be weak on the basis of studies of the analogous molybdenum compounds, and may be obscured by ligand resonances. A sample of $\left\{\left[\mathrm{HIPTN} \mathrm{N}_{3} \mathrm{~N}\right] \mathrm{VN}_{2}\right\} \mathrm{K}$ in THF to which 18-Crown-6 had been added (one equivalent) shows $v_{\mathrm{NN}}=1884 \mathrm{~cm}^{-1}$, while in $\mathrm{C}_{6} \mathrm{D}_{6} v_{\mathrm{NN}}$ is observable at 1881 $\mathrm{cm}^{-1}$. Both results are consistent with essentially complete solvation of the potassium ion by 18-Crown-6 or THF (in THF solvent). Therefore we can conclude that $v_{\mathrm{NN}}$ in the "free" $\left\{\left[\mathrm{HIPTN} \mathrm{N}_{3} \mathrm{~N}\right] \mathrm{VN}_{2}\right\}^{-}$ion is approximately $30 \mathrm{~cm}^{-1}$ higher than what it is in the "free" $\left\{\left[\mathrm{HIPTN} \mathrm{N}_{3} \mathrm{~N}\right] \mathrm{MoN}_{2}\right\}^{-}$ion. This finding is consistent with the expected stronger $\pi$ back donation of electron density into dinitrogen from "Mo(2+)" versus "V(2+)".

Attempts to protonate the $\left\{\left[\mathrm{HIPTN}_{3} \mathrm{~N}\right] \mathrm{VN}_{2}\right\}^{-}$ion with [2,6-lutidinium]BAr ${ }_{4}$ or $\mathrm{H}\left(\mathrm{Et}_{2} \mathrm{O}\right)_{2} \mathrm{BAr}$ ${ }_{4}\left(\mathrm{Ar}^{\prime}=3,5-\left(\mathrm{CF}_{3}\right)_{2} \mathrm{C}_{6} \mathrm{H}_{3}\right)$ under a variety of conditions so far has led only to solutions that contain multiple products from which no pure product could be isolated.

\section{Synthesis of $\left[\mathrm{HIPTN}{ }_{3} \mathrm{~N}\right] \mathrm{V}\left(\mathrm{NH}_{3}\right)$}

Exposure of a degassed solution of $\left[\mathrm{HIPTN}_{3} \mathrm{~N}\right] \mathrm{V}(\mathrm{THF})$ in pentane to $\mathrm{NH}_{3}$ results in the immediate lightening of the solution's green color. [HIPTN $\left.\mathrm{N}_{3} \mathrm{~N}\right] \mathrm{V}\left(\mathrm{NH}_{3}\right)$ can be isolated from this solution and recrystallized from pentane, although it is much more soluble than $\left[\mathrm{HIPTN}_{3} \mathrm{~N}\right] \mathrm{V}$ (THF); it is best crystallized from hexamethyldisiloxane. [ $\left.\mathrm{HIPTN}_{3} \mathrm{~N}\right] \mathrm{V}\left(\mathrm{NH}_{3}\right)$ is also more temperature sensitive than $\left[\mathrm{HIPTN} \mathrm{N}_{3} \mathrm{~N}\right] \mathrm{V}(\mathrm{THF})$, to the point of not being stable at room temperature over several months as evidenced by the formation of a black solid which can be washed away with tetramethylsilane. 
An X-ray study of [HIPTN $\left.{ }_{3} \mathrm{~N}\right] \mathrm{V}\left(\mathrm{NH}_{3}\right)$ reveals it to have the expected structure (Tables 1 and 2, Figure 3) which is similar to that of [HIPTN $\left.{ }_{3} \mathrm{~N}\right] \mathrm{V}(\mathrm{THF})$. It should be noted that the $\mathrm{V}-\mathrm{X}$ distances in $\left[\mathrm{HIPTN}_{3} \mathrm{~N}\right] \mathrm{V}(\mathrm{THF})(2.1399(15) \AA)$ and $\left[\mathrm{HIPTN}_{3} \mathrm{~N}\right] \mathrm{V}\left(\mathrm{NH}_{3}\right)(2.1623(8) \AA)$ are essentially the same, as are other corresponding distances and angles in the two species (Table 2). In $\left[\mathrm{HIPTN}{ }_{3} \mathrm{~N}\right] \mathrm{V}\left(\mathrm{NH}_{3}\right)$ the $\mathrm{X}-\mathrm{V}-\mathrm{N}-\mathrm{C}$ dihedral angles (where $\mathrm{X}$ is the atom bound to $\mathrm{V}$ in the apical pocket) are no larger than $5^{\circ}$, compared to up to $20^{\circ}$ in $\left[\mathrm{HIPTN}_{3} \mathrm{~N}\right] \mathrm{V}(\mathrm{THF})$. The steric demands of the ammonia ligand in the apical pocket are simply not as great as the steric demands of the THF ligand.

An attempt to convert $\left[\mathrm{HIPTN}_{3} \mathrm{~N}\right] \mathrm{V}\left(\mathrm{NH}_{3}\right)$ into $\left\{\left[\mathrm{HIPTN}_{3} \mathrm{~N}\right] \mathrm{VN}_{2}\right\}^{-}$through addition of one equivalent of potassium graphite in heptane under dinitrogen led to formation of an unidentified black material. No electrochemical studies on $\left[\mathrm{HIPTN}{ }_{3} \mathrm{~N}\right] \mathrm{V}\left(\mathrm{NH}_{3}\right)$ or $\left\{\left[\mathrm{HIPTN}_{3} \mathrm{~N}\right] \mathrm{VN}_{2}\right\}^{-}$have yet been carried out.

\section{Synthesis of [HIPTN $\left.{ }_{3} \mathrm{~N}\right] \mathrm{V}=\mathrm{X}$ species}

Addition of 2-methylaziridine to a toluene solution of $\mathbf{V}(\mathrm{THF})$ at room temperature produces a red solution that remains red over a period of $12 \mathrm{~h}$. NMR studies suggest that the species that is present at this stage is paramagnetic. There is no noticeable color change upon heating this solution at $80^{\circ} \mathrm{C}$ over a period of $12 \mathrm{~h}$, but diamagnetic $\left[\mathrm{HIPTN}_{3} \mathrm{~N}\right] \mathrm{V}=\mathrm{NH}$ can be isolated from this solution and recrystallized readily from pentane as large blocks. The ${ }^{1} \mathrm{H}$ NMR spectrum of $\left[\mathrm{HIPTN} \mathrm{N}_{3} \mathrm{~N}\right] \mathrm{V}=\mathrm{NH}$ contains sharp resonances while the ${ }^{51} \mathrm{~V}$ NMR spectrum contains a broad resonance at $-334 \mathrm{ppm}(2365 \mathrm{~Hz}$ wide at half-height). No detectable coupling of ${ }^{51} \mathrm{~V}$ to ${ }^{15} \mathrm{~N}$ could be observed in the ${ }^{51} \mathrm{~V}$ NMR spectrum of $\mathbf{V}={ }^{15} \mathrm{NH}$. The magnitude of the coupling of ${ }^{51} \mathrm{~V}$ to ${ }^{15} \mathrm{~N}$ is likely to be of the order of $100-200 \mathrm{~Hz},{ }^{19}$ which is much too small to observe in such a broad peak. No resonance could be found for the imido hydrogen in the proton NMR spectrum, a circumstance that also was encountered for $\left[\mathrm{Me}_{3} \mathrm{SiN}_{3} \mathrm{~N}\right] \mathrm{V}=\mathrm{NH}$. $16 \mathrm{~b}$ Vanadium NMR shifts in $\left[\mathrm{HIPTN}_{3} \mathrm{~N}\right] \mathrm{V}=\mathrm{X}$ and $\left[\mathrm{Me}_{3} \mathrm{SiN}_{3} \mathrm{~N}\right] \mathrm{V}=\mathrm{X}$ species are listed in Table 3.

It is interesting to note that $\left[\mathrm{HIPTN}_{3} \mathrm{~N}\right] \mathrm{V}=\mathrm{NH}$ also can be prepared through addition of 2 equivalents of $\mathrm{LiN}\left(\mathrm{SiMe}_{3}\right)_{2}$ to $\mathbf{V}\left(\mathrm{NH}_{3}\right)$ followed by 2 equivalents of $\left[\mathrm{FeCp}_{2}\right] \mathrm{OTf}$. We propose that this reaction consists of alternating oxidations followed by deprotonations, i.e, $\mathbf{V}\left(\mathrm{NH}_{3}\right) \rightarrow$ $\mathbf{V}\left(\mathrm{NH}_{3}\right)^{+} \rightarrow \mathbf{V}\left(\mathrm{NH}_{2}\right) \rightarrow \mathbf{V}\left(\mathrm{NH}_{2}\right)^{+} \rightarrow \mathbf{V}=\mathrm{NH}$. Conversion of $\mathbf{V}\left(\mathrm{NH}_{3}\right)$ into $\mathbf{V}=\mathrm{NH}$ is quite facile, occurring even without addition of $\mathrm{LiN}\left(\mathrm{SiMe}_{3}\right)_{2}$. Addition of even 1 equivalent of $\left[\mathrm{FeCp}_{2}\right]$ OTf to $\mathbf{V}\left(\mathrm{NH}_{3}\right)$ results in formation of $\mathbf{V}=\mathrm{NH}$ as the only identifiable product. This reaction was employed to synthesize $\mathbf{V}={ }^{15} \mathrm{NH}$ and thereby identify the $\mathrm{N}-\mathrm{H}$ stretch in its infrared spectrum; in $\mathrm{C}_{6} \mathrm{D}_{6} v 15_{\mathrm{NH}}=3351 \mathrm{~cm}^{-1}$ compared to $v 14_{\mathrm{NH}}=3360 \mathrm{~cm}^{-1}$. Like $\left[\mathrm{Me}_{3} \mathrm{SiN}_{3} \mathrm{~N}\right]$ $\mathrm{V}=\mathrm{NH}, \mathbf{V}=\mathrm{NH}$ is not especially susceptible to oxidation and thus is relatively stable in air. In comparison to $\mathbf{V}=\mathrm{NH}$ it should be noted that $\mathrm{d}^{1}\left[\mathrm{HIPTN}_{3} \mathrm{~N}\right] \mathrm{Mo}=\mathrm{NH}$ is unstable, losing dihydrogen to yield $\left[\mathrm{HIPTN}_{3} \mathrm{~N}\right] \mathrm{Mo} \equiv \mathrm{N}$, which is relatively stable toward air. The mechanism of dihydrogen formation is not known.

Treatment of $\mathbf{V}(\mathrm{THF})$ with $\mathrm{Me}_{3} \mathrm{SiN}_{3}$ yields orange $\mathbf{V}=\mathrm{NSiMe}_{3}$ in variable yield depending on the length of time that the reaction mixture is heated. The reaction must be heated, but heating for too long produces low yields; the optimum conditions for maximum yield were not determined. The ${ }^{1} \mathrm{H}$ NMR spectrum of $\mathbf{V}=\mathrm{NSiMe}_{3}$ is typical of a diamagnetic complex with sharp proton resonances and a broad ${ }^{51} \mathrm{~V}$ NMR resonance at $-276.31 \mathrm{ppm}(1326 \mathrm{~Hz}$ wide at half-height). The $\mathrm{Me}_{3} \mathrm{Si}$ resonance $(0.12 \mathrm{ppm})$ is shifted upfield slightly from where it is in $\left[\mathrm{Me}_{3} \mathrm{SiN}_{3} \mathrm{~N}\right] \mathrm{V}=\mathrm{NSiMe}_{3}(\delta=0.55 \mathrm{ppm}) .{ }^{16 \mathrm{~b}}$

Addition of $\mathrm{S}_{8}$ to a stirred solution of $\mathbf{V}$ (THF) yields dark green $\mathbf{V}=\mathrm{S}$, which displays a sharp ${ }^{1} \mathrm{H}$ NMR spectrum and a sharp ${ }^{51} \mathrm{~V}$ NMR resonance at $756 \mathrm{ppm}(30 \mathrm{~Hz}$ wide at halfheight). Even after multiple recrystallizations, a small (ca. $2-3 \%$ by integration) ${ }^{51} \mathrm{~V}$ resonance 
can be observed for an unidentified vanadium complex. The same phenomenon is observed in $\mathbf{V}=\mathrm{O}$ (vide infra), although the unidentified species in $\mathbf{V}=\mathrm{O}$ samples is not the same as that in $\mathbf{V}=\mathrm{S}$ samples. $\left[\mathrm{Me}_{3} \mathrm{SiN}_{3} \mathrm{~N}\right] \mathrm{V}=\mathrm{S}$ was prepared also simply through addition of sulfur to $\left[\mathrm{Me}_{3} \mathrm{SiN}_{3} \mathrm{~N}\right] \mathrm{V} .{ }^{16 b}$

Addition of propylene oxide to a solution of $\mathbf{V}$ (THF) led to formation of a purple solution. Heating is required to generate diamagnetic purple $\mathbf{V}=\mathrm{O}$, which can be isolated as a microcrystalline powder and can be recrystallized from pentane. Its vanadium NMR spectrum shows a resonance at $-116 \mathrm{ppm}(785 \mathrm{~Hz}$ wide at half-height); a small impurity is present with a vanadium resonance at $-69 \mathrm{ppm}$, even in spectra of multiply recrystallized material. An attempt to synthesize $\mathrm{V}=\mathrm{O}$ from $\mathrm{Cl}_{3} \mathrm{~V}=\mathrm{O}$, as in the synthesis of $\left[\mathrm{C}_{6} \mathrm{~F}_{5} \mathrm{~N}_{3} \mathrm{~N}\right] \mathrm{V}=\mathrm{O}$, $15 \mathrm{a}$ yielded multiple products according to ${ }^{51} \mathrm{~V}$ NMR spectra, and was abandoned in favor of the propylene oxide route.

\section{Other Reactions}

Attempts to deprotonate $\mathbf{V}=\mathrm{NH}$ with $\mathrm{LiN}\left(\mathrm{SiMe}_{3}\right)_{2}$ or $\mathrm{LiNH}-i$-Pr produced no reaction, while use of $\mathrm{Li}-n$-Bu led to unidentified decomposition products. In contrast, it has been reported that the reaction between $\left[\mathrm{Me}_{3} \mathrm{SiN}_{3} \mathrm{~N}\right] \mathrm{V}=\mathrm{NH}$ and $\mathrm{LiN}\left(\mathrm{SiMe}_{3}\right)_{2}$ followed by addition of $\mathrm{Me}_{3} \mathrm{SiCl}$ generates $\left[\mathrm{Me}_{3} \mathrm{SiN}_{3} \mathrm{~N}\right] \mathrm{V}=\mathrm{NSiMe}_{3}$; although $\left[\mathrm{Me}_{3} \mathrm{SiN}_{3} \mathrm{~N}\right] \mathrm{V}=\mathrm{NLi}$ was not isolated and characterized, it presumably is formed as an intermediate. ${ }^{16 b}$ Attempts to remove the TMS group from $\mathbf{V}=\mathrm{NSiMe}_{3}$ using LiNH-i-Pr, a method employed ${ }^{20}$ for the synthesis of $\left[\left(\mathrm{Ph}_{2} \mathrm{~N}\right)_{3} \mathrm{VN}\right] \mathrm{Na}(\mathrm{THF})_{3},{ }^{9} \mathrm{c}$ yielded no reaction at room temperature and decomposition upon heating. A similar result was observed employing $n$-Bu $\mathrm{Bu}_{4} \mathrm{NF}$. Attempts to generate $\{\mathbf{V}(\mathrm{N})\}^{-}$in reactions between $\mathbf{V}$ (THF) and $\mathrm{NaN}_{3}$ or $n$ - $\mathrm{Bu}_{4} \mathrm{NN}_{3}$ so far have failed. Anionic vanadium nitride complexes in the literature $9 \mathrm{c}, 21$ have been isolated that are supported by three monoamido ligands.

Exposure of a degassed pentane solution of $\mathbf{V}$ (THF) to an atmosphere of $\mathrm{CO}$ produces a redgold solution of what we presume contains $\mathbf{V}(\mathrm{CO})$ on the basis of a $v_{\mathrm{CO}}$ stretch at 2076 $\mathrm{cm}^{-1}$ in the IR spectrum and literature precedent for formation of a variety of early metal triamidoamine $\mathrm{CO}$ complexes. ${ }^{1,2}$ When ${ }^{13} \mathrm{CO}$ is employed $v 13_{\mathrm{CO}}$ can be observed at 2030 $\mathrm{cm}^{-1}$ and $v 13_{\mathrm{C}} 18_{\mathrm{O}}$ at $1980 \mathrm{~cm}^{-1}$. Clearly V(III) is capable of binding carbon monoxide, as expected, but not dinitrogen.

\section{Evaluation of Activity for Dinitrogen Reduction}

We have isolated three species that one might suspect could be intermediates in a catalytic reduction of dinitrogen (Scheme 1), namely $\left\{\mathbf{V N}_{2}\right\}^{-}, \mathbf{V}=\mathrm{NH}$, and $\mathbf{V}\left(\mathrm{NH}_{3}\right)$. We also have been able to readily convert $\mathbf{V}\left(\mathrm{NH}_{3}\right)$ to $\mathbf{V}=\mathrm{NH}$, which by microscopic reversibility implies that conversion of $\mathbf{V}=\mathrm{NH}$ to $\mathbf{V}\left(\mathrm{NH}_{3}\right)$ is possible. Therefore, we were interested in the possibility that vanadium species might serve as catalysts for the reduction of dinitrogen by protons and electrons under conditions that have been successful for analogous molybdenum catalysts 2 using $\mathrm{CrCp}_{2}{ }_{2}$ as the reducing agent and 2,6-lutidinium $\mathrm{BAr}_{4}{ }_{4}$ as the acid source. Reactions were carried out in the manner described for [HIPTN $\left.\mathrm{H}_{3} \mathrm{~N}\right] \mathrm{Mo}$ complexes and variations thereof using $\mathbf{V}(\mathrm{THF}),\left\{\mathbf{V N}_{2}\right\}^{-}$, and $\mathbf{V}=\mathrm{NH}$ as the initial species. No ammonia was generated when $\mathbf{V}$ (THF) was employed, while $\left\{\mathbf{V N}_{2}\right\}^{-}$and $\mathbf{V}=\mathrm{NH}$ yielded 0.20 and 0.78 equivalents respectively. We presume that no ammonia is formed from dinitrogen in the atmosphere, i.e., under these conditions vanadium is not a catalyst for dinitrogen reduction.

\section{CONCLUSIONS}

We have been able to prepare a variety of $\left[\mathrm{HIPTN}_{3} \mathrm{~N}\right] \mathrm{V}(\mathbf{V})$ species, including three $\left(\left\{\mathbf{V N}_{2}\right\}\right.$ $\mathrm{K}, \mathbf{V}=\mathrm{NH}$, and $\mathbf{V}\left(\mathrm{NH}_{3}\right)$ ) that are relevant to a hypothetical reduction of dinitrogen. While the 
chemistry of $\mathbf{V}$ complexes is largely tractable and well-behaved, no ammonia was formed from dinitrogen using $\mathbf{V}$ (THF), $\left\{\mathbf{V N}_{2}\right\}^{-}$, or $\mathbf{V}=\mathrm{NH}$ as the initial species under conditions that were successful in the analogous Mo system. Although there are hints as to what some of the problems might be, more quantitative studies are needed in order to provide support. Certainly one of the concerns is the fact that the trianionic triamidoamine ligand demands that all charges of intermediates be one less than what they are in the analogous Mo system. Perhaps the most serious problem is that the nitride intermediate must be an anion. However, there are clearly other hurdles in a hypothetical dinitrogen reduction scheme, among them the decomposition of $\mathbf{V}\left(\mathrm{NH}_{3}\right)$ on reduction, at least with potassium graphite as the reducing agent. In future studies we hope to further probe the $\left[\mathrm{HIPTN}_{3} \mathrm{~N}\right] \mathrm{V}$ system in order to see if conditions can be found that will allow turnover.

\section{Experimental Section}

General-All experiments involving air and/or moisture sensitive complexes or reactions were performed under nitrogen in a Vacuum Atmospheres drybox or using standard Schlenk techniques with glassware stored in an oven at $\sim 190^{\circ} \mathrm{C}$ for at least 12 hours prior to use. Pentane was washed with $\mathrm{HNO}_{3} / \mathrm{H}_{2} \mathrm{SO}_{4}$ (5:95 by volume), sodium bicarbonate, and water, dried over $\mathrm{CaCl}_{2}$, and then sparged with nitrogen and passed through an alumina column followed by storage over $\mathrm{Na}$ /benzophenone and vacuum transfer prior to use. Dry and deoxygenated benzene was purchased from Aldrich and passed through Q5 and alumina columns. Heptane, benzene- $d_{6}$ and toluene- $d_{8}$ were dried over Na/benzophenone then degassed (freeze-pumpthaw) and vacuum transferred prior to use. THF, diethyl ether and toluene were pre-dried by passage through an alumina column followed by storage over $\mathrm{Na} /$ benzophenone. They were degassed (freeze-pump-thaw) and vacuum transferred prior to use. All solvents were stored over $4 \AA$ A molecular sieves in a drybox after transfer.

$\mathrm{VCl}_{3}$ (Strem), $\mathrm{CO}$ (Aldrich, passed through dry ice/acetone), ${ }^{13} \mathrm{CO}$ (Matheson, passed through dry ice/acetone), $\mathrm{NH}_{3}$ (BOC, condensed onto $\mathrm{Na}$ sand), ${ }^{15} \mathrm{NH}_{3}$ (Cambridge Isotope labs, condensed onto $\mathrm{Na}$ sand), ${ }^{15} \mathrm{~N}_{2}$ (Cambridge Isotope Labs), LiN(TMS) ${ }_{2}$ (Aldrich, sublimed), 2-methylaziridine (Aldrich, vacuum transferred and stored at $c a .-40{ }^{\circ} \mathrm{C}$ ), (TMS) $\mathrm{N}_{3}$ (Acros Organics), propylene oxide (Aldrich), 18-Crown-6 (Aldrich, dried in vacuo), 15-Crown-5 (Acros Organics, degassed and stored over $4 \AA$ molecular sieves) were purchased as used as received or purified as indicated.

$\mathrm{H}_{3}\left[\mathrm{HIPTN}_{3} \mathrm{~N}\right],{ }^{3} \mathrm{VCl}_{3}(\mathrm{THF})_{3}, 22\left[\mathrm{FeCp}_{2}\right] \mathrm{OTf},{ }^{23}$ and $n-\mathrm{Bu}_{4} \mathrm{NN}_{3}{ }^{24}$ were synthesized via literature procedures. Potassium graphite was synthesized by stirring a 1:8 mixture of potassium:graphite under partial vacuum for 2 hours using a glass stirbar at $\sim 200{ }^{\circ} \mathrm{C}$.

${ }^{1} \mathrm{H}$ NMR spectra were obtained on a Varian mercury $(300 \mathrm{MHz})$ or Inova $(500 \mathrm{MHz})$ spectrometer and were referenced to the residual protio-solvent peak. ${ }^{51} \mathrm{~V}$ NMR spectra were obtained on a Varian Inova (131.5 MHz) spectrometer outfitted with an inverse probe and externally referenced to a commercial sample of $\mathrm{VOCl}_{3}\left(\delta\left({ }^{51} \mathrm{~V}\right)=0 \mathrm{ppm}\right)$. Infrared spectra were obtained on a Nicolet Avatar 360 FT-IR spectrometer using a demountable liquid cell ( $0.2 \mathrm{~mm}$ Teflon or lead spacer with $\mathrm{KBr}$ plates). UV/Vis spectra were obtained on a HewlettPackard 8452A Diode Array Spectrophotometer equipped with a Hewlett Packard 89090A peltier temperature control accessory with the solvent contribution manually subtracted using a standard background. Magnetic measurements (Evans method ${ }^{25,26}$ ) employed the shift of the toluene methyl group. The sample was dissolved in a 4:1 (by volume) mixture of $\mathrm{C}_{6} \mathrm{D}_{6}$ :toluene and a concentric sealed capillary filled with toluene was added; multiple determinations are listed as separate results. Elemental Analyses were performed by H. Kolbe Microanalytics Laboratory, Mülheim an der Ruhr, Germany. 
X-ray diffraction data were collected using a Siemens Platform three-circle diffractometer with graphite-monochromated Mo K $\alpha$ radiation $(\lambda=0.71073 \AA)$, performing $\phi$ - and $\omega$-scans. Data for the V(THF) structure was collected at $100 \mathrm{~K}$ on a Bruker-AXS Smart Apex CCD detector, all other structural data was collected at $193 \mathrm{~K}$ using a Bruker Smart $1000 \mathrm{CCD}$ detector. The structures were solved by direct methods using SHELXS ${ }^{27}$ and refined against $\mathrm{F}^{2}$ on all data by full-matrix least squares with SHELXL-97. ${ }^{28}$ All non-hydrogen atoms were refined anisotropically. Unless otherwise indicated in the discussion, all hydrogen atoms were included into the model at their geometrically calculated positions and refined using a riding model. Thermal ellipsoid drawings were generated using ORTEP-3. ${ }^{29}$

Refinement of the $\mathbf{V}\left(\mathrm{NH}_{3}\right)$ structure did not converge well, and required damping. As a result, the calculated standard uncertainties are underrated. In addition, the HIPT ${ }^{3-}$ ligand is heavily disordered. Some of those disorders could be refined with the help of similarity restraints on 1-2 and 1-3 distances and displacement parameters as well as rigid bond restraints for anisotropic displacement parameters. The ammonia hydrogens could be found in a Fourier difference map and refined semi-freely with the help of distance restraints

[HIPTN $\left.{ }_{3} \mathbf{N}\right] \mathbf{V}$ (THF) $-\mathrm{VCl}_{3}(\mathrm{THF})_{3}(1.17 \mathrm{~g}, 3.14 \mathrm{mmol})$ and $\mathrm{H}_{3}\left[\mathrm{HIPTN}_{3} \mathrm{~N}\right](5.00 \mathrm{~g}, 3.15$ $\mathrm{mmol}$ ) were added to a $100 \mathrm{~mL}$ flask equipped with a $0-8$ Teflon valve via a solid addition funnel followed by THF ( $\mathrm{ca} .50 \mathrm{~mL}$ ). The flask was sealed and the resulting purple adduct was allowed to stir for 1 hour. (TMS $)_{2} \mathrm{NLi}(1.53 \mathrm{~g}, 9.16 \mathrm{mmol})$ was then added, resulting in a dark green solution within minutes. After stirring the reaction mixture for one hour, the THF was removed in vacuo to minimum pressure (ca. 5-10 mTorr) at room temperature. The resulting solid was taken up in pentane and the solution was filtered through celite to remove $\mathrm{LiCl}$. The filtrate was concentrated and the product obtained as a lime green solid through crystallization at $c a .-35^{\circ} \mathrm{C}$. This solid was again dried at room temperature in vacuo to minimum pressure to yield the lime green product $(4.6 \mathrm{~g}, 86 \% \text { ). Substituting (TMS })_{2} \mathrm{NK}$ for (TMS) ${ }_{2} \mathrm{NLi}$ gave the same product $(2.4 \mathrm{~g}, 45 \%)$. UV/Vis $\lambda_{\max }(\mathrm{nm}), \varepsilon\left(\mathrm{M}^{-1} \cdot \mathrm{cm}^{-1}\right)$ : heptane $(260(\mathrm{sh}), 6.6 \times$ $\left.10^{4} ; 306,1.9 \times 10^{4} ; 350(\mathrm{sh}), 1.1 \times 10^{4} ; 404(\mathrm{sh}), 5.8 \times 10^{3}\right) ; \mu_{\mathrm{eff}}=2.51,2.54,2.55 \mathrm{BM}$; Anal. Calcd for $\mathrm{C}_{118} \mathrm{H}_{167} \mathrm{~N}_{4}$ VO: C, 79.95; H, 7.85; N, 2.28; Cl, 0.00. Found: C, 80.11; H, 7.92; N, $2.25 ; \mathrm{Cl}, 0.00$.

\{[HIPTN $\mathbf{H}_{\mathbf{3}} \mathbf{N}$ ]VN $\mathbf{N}_{\mathbf{2}}$ \}K - $\left[\mathrm{HIPTN}_{3} \mathrm{~N}\right] \mathrm{V}$ (THF) $(300 \mathrm{mg}, 0.176 \mathrm{mmol})$ and $\mathrm{KC}_{8}(37.5 \mathrm{mg}, 0.277$ $\mathrm{mmol}$ ) were added to a $20 \mathrm{~mL}$ scintillation vial along with a glass-coated stir-bar and $5-10$ $\mathrm{mL}$ of solvent (typically THF, but also DME, ether, benzene, or toluene). Using ethereal solvents, the solution turns red within minutes (overnight in the case of toluene or benzene) and was filtered through glass wool in a pipet to remove the graphite and excess $\mathrm{KC}_{8}$. The solvent was removed in vacuo to afford red solid; IR(THF) $\mathrm{cm}^{-1} 1883\left(v_{\mathrm{NN}}\right)$.

\{[HIPTN ${ }_{3} \mathbf{N} \mathbf{V}^{15} \mathbf{N}_{2}$ \}K- HIPTN $\left._{3} \mathrm{~N}\right] \mathrm{V}$ (THF) $(52.0 \mathrm{mg}, 30 \mu \mathrm{mol})$ and $\mathrm{KC}_{8}(9.4 \mathrm{mg}, 70 \mu \mathrm{mol})$ were added to a J. Young tube. THF ( $c a .1 .6-2 \mathrm{~mL}$ ) was then added to a second J. Young tube. Both J. Young tubes were connected to a transfer bridge. The tube containing solid was evacuated, while the tube containing solvent was degassed using 5 freeze-pump-thaw cycles. The THF was then vacuum transferred onto the solid, but kept frozen in liquid nitrogen. This tube was attached to a gas transfer bridge and filled with $c a$. 13 equivalents of ${ }^{15} \mathrm{~N}_{2}$. The tube was subsequently placed in a dry ice/acetone bath to react with occasional shaking. Once the sample was fully thawed it was allowed to warm to room temperature and the solution was filtered through glass wool in a pipet. The resultant red solution was used directly for IR measurements; IR(THF) $\mathrm{cm}^{-1} 1821\left(v_{\mathrm{NN}}\right)$.

\{[HIPTN ${ }_{3}$ N]VN 2 $_{\text {\}K(18-crown-6)-[HIPTN }}$ N]V(THF) (300 mg, 0.176 mmol), $\mathrm{KC}_{8}$ (38.1 $\mathrm{mg}, 0.282 \mathrm{mmol})$, and 18 -crown-6 (49.8 $\mathrm{mg}, 0.188 \mathrm{mmol})$ were added to a $20 \mathrm{~mL}$ scintillation vial followed by a glass stirbar and DME ( $c a .4 \mathrm{~mL})$. The solution turned red immediately and 
was allowed to stir for 30 minutes. Graphite was removed by filtration through glass wool in a pipet followed by removal of the solvent in vacuo. The sample was triturated with pentane and collected on a glass frit to yield 3 quantitatively. $\operatorname{IR}\left(\mathrm{C}_{6} \mathrm{D}_{6}\right) \mathrm{cm}^{-1} 1881\left(v_{\mathrm{NN}}\right) ; \operatorname{IR}(\mathrm{THF})$ $\mathrm{cm}^{-1} 1884\left(v_{\mathrm{NN}}\right)$. Anal. Calcd for $\mathrm{C}_{126} \mathrm{H}_{183} \mathrm{~N}_{6} \mathrm{VO}_{6} \mathrm{~K}: \mathrm{C}, 76.90 ; \mathrm{H}, 9.37 ; \mathrm{N}, 4.27$. Found: $\mathrm{C}$, $77.08 ; \mathrm{H}, 9.28 ; \mathrm{N}, 4.22$.

[HIPTN $\left.{ }_{3} \mathbf{N}\right] \mathbf{V}\left(\mathrm{NH}_{3}\right)$ - HIPTN $\left._{3} \mathrm{~N}\right] \mathrm{V}(\mathrm{THF})(1.00 \mathrm{~g}, 0.59 \mathrm{mmol})$ in a $100 \mathrm{~mL}$ solvent bomb type flask equipped with a Teflon valve was dissolved in pentane and exposed to $c a$. $1 \mathrm{~atm}$. of $\mathrm{NH}_{3}$. The color immediately changed to a lighter shade of green and removal of the volatiles in vacuo yielded a green solid quantitatively. Crystallization of the crude product from a supersaturated pentane solution at $c a .-35^{\circ} \mathrm{C}$ yielded green flakes $(661 \mathrm{mg}, 68 \%)$ : UV/Vis $\lambda_{\max }(\mathrm{nm}), \varepsilon\left(\mathrm{M}^{-1} \cdot \mathrm{cm}^{-1}\right)$ : heptane $\left(214,1.43 \times 10^{5} ; 280,1.55 \times 10^{4} ; 316,1.91 \times 10^{4} ; 352,1.70\right.$ $\left.\times 10^{4}\right) ; \operatorname{IR}\left(\mathrm{C}_{6} \mathrm{D}_{6}\right) \mathrm{cm}^{-1} 3358\left(v_{\mathrm{NH}}\right) ; \mu_{\mathrm{eff}}=2.22,2.23,2.24 \mathrm{BM}$ (two different samples). Anal. Calcd for $\mathrm{C}_{114} \mathrm{H}_{162} \mathrm{~N}_{5} \mathrm{~V}$ : C, 82.81; H, 9.88; N, 4.24. Found: C, 82.69; H, 9.76; N, 4.21.

[HIPTN $\left.{ }_{3} \mathbf{N}\right] \mathbf{V}\left({ }^{15} \mathrm{NH}_{3}\right)$ - $\left[\mathrm{HIPTN}_{3} \mathrm{~N}\right.$ ]V(THF) $(500 \mathrm{mg}, 0.29 \mathrm{mmol})$ in a $50 \mathrm{~mL}$ solvent bomb type flask equipped with a Teflon valve was dissolved in pentane and exposed to $c a .1 \mathrm{~atm}$ of ${ }^{15} \mathrm{NH}_{3}$. The color immediately changed to green, and the volatiles were removed in vacuo. Crystallization of the crude product from a supersaturated hexamethyldisiloxane solution at $c a .-35{ }^{\circ} \mathrm{C}$ yielded green flakes $(402 \mathrm{mg}, 83 \%)$. $\operatorname{IR}\left(\mathrm{C}_{6} \mathrm{D}_{6}\right) \mathrm{cm}^{-1} 3349\left(v_{\mathrm{NH}}\right)$.

[HIPTN ${ }_{3} \mathbf{N}$ ]V=NH-[HIPTN $\left.{ }_{3} \mathrm{~N}\right] \mathrm{V}$ (THF) $(500 \mathrm{mg}, 0.29 \mathrm{mmol})$ was dissolved in $c a .20 \mathrm{~mL}$ of toluene in a $50 \mathrm{~mL}$ solvent bomb type flask equipped with a Teflon valve. 2-Methylaziridine $(41.4 \mu \mathrm{L}, 0.59 \mathrm{mmol})$ was added and the reaction was left to stir at room temperature for $\sim 12$ hours. The resulting red solution was then heated at $80^{\circ} \mathrm{C}$ for 12 hours. The volatiles were removed in vacuo, and the resulting solid was crystallized from a supersaturated pentane solution at $c a .-35{ }^{\circ} \mathrm{C}$ to give large dark red blocks $(427 \mathrm{mg}, 88 \%):{ }^{1} \mathrm{H}$ NMR $\left(\mathrm{C}_{6} \mathrm{D}_{6}\right) \delta 7.54$ (br s, 6H), $7.19(\mathrm{~s}, 12 \mathrm{H}), 6.45(\mathrm{~s}, 3 \mathrm{H}), 3.72(\mathrm{br} \mathrm{t}, 6 \mathrm{H}), 3.09$ (sept, $\left.\mathrm{J}_{\mathrm{HH}}=6.8 \mathrm{~Hz}, 12 \mathrm{H}\right), 2.92$ $\left(\mathrm{sept}, \mathrm{J}_{\mathrm{HH}}=6.8 \mathrm{~Hz}, 6 \mathrm{H}\right), 2.15(\mathrm{br} \mathrm{t}, 6 \mathrm{H}), 1.36\left(\mathrm{~d}, \mathrm{~J}_{\mathrm{HH}}=6.9 \mathrm{~Hz}, 36 \mathrm{H}\right), 1.22\left(\mathrm{~d}, \mathrm{~J}_{\mathrm{HH}}=6.8 \mathrm{~Hz}\right.$, $36 \mathrm{H}), 1.07\left(\mathrm{~d}, \mathrm{~J}_{\mathrm{HH}}=6.6 \mathrm{~Hz}, 36 \mathrm{H}\right) ;{ }^{51} \mathrm{~V}$ NMR $\left(\mathrm{C}_{6} \mathrm{D}_{6}\right)-334(\mathrm{br} \mathrm{s}) ; \mathrm{UV} / \mathrm{V}$ is $\lambda_{\max }(\mathrm{nm}), \varepsilon$ $\left(\mathrm{M}^{-1} \cdot \mathrm{cm}^{-1}\right)$ : heptane $\left(266,3.2 \times 10^{4} ; 376,1.98 \times 10^{4} ; 466,2.18 \times 10^{4}\right) ; \mathrm{IR}\left(\mathrm{C}_{6} \mathrm{D}_{6}\right) \mathrm{cm}^{-1} 3360$ $\left(v_{\mathrm{NH}}\right)$. Anal. Calcd for $\mathrm{C}_{114} \mathrm{H}_{160} \mathrm{~N}_{5} \mathrm{~V}: \mathrm{C}, 82.91 ; \mathrm{H}, 9.77 ; \mathrm{N}, 4.24$. Found: C, 82.74; H, 9.85; N, 4.18

[HIPTN ${ }_{3} \mathrm{~N} \mathbf{V}^{15} \mathrm{NH}-\left[\mathrm{HIPTN}{ }_{3} \mathrm{~N}\right] \mathrm{V}\left({ }^{15} \mathrm{NH}_{3}\right)(50 \mathrm{mg}, 30 \mu \mathrm{mol})$ and $(\mathrm{TMS})_{2} \mathrm{NLi}(10 \mathrm{mg}, 60$ $\mu \mathrm{mol})$ were dissolved in diethyl ether in a $20 \mathrm{~mL}$ scintillation vial. [ $\left.\mathrm{FeCp}_{2}\right] \mathrm{OTf}(20 \mathrm{mg}, 60$ $\mu \mathrm{mol}$ ) was added to a stirred solution to give a red solution immediately. The volatiles were removed in vacuo. Pentane was added to the resulting residue and the solution was filtered through Celite. The solvent was removed in vacu at $\sim 70{ }^{\circ} \mathrm{C}$. $\mathrm{IR}\left(\mathrm{C}_{6} \mathrm{D}_{6}\right) \mathrm{cm}^{-1} 3351\left(v_{\mathrm{NH}}\right)$.

[HIPTN $\mathbf{H}_{3} \mathbf{N}$ ]V=N(TMS)-[HIPTN $\left.{ }_{3} \mathrm{~N}\right] \mathrm{V}$ (THF) $(300 \mathrm{mg}, 0.18 \mathrm{mmol})$ was added to a $50 \mathrm{~mL}$ solvent bomb type flask with a Teflon valve and dissolved in $c a .10 \mathrm{~mL}$ of toluene. (TMS) $\mathrm{N}_{3}(47 \mu \mathrm{L}, 0.35 \mathrm{mmol})$ was added followed by another $1-2 \mathrm{~mL}$ of toluene to wash the valve stem of the flask. The reaction was stirred at $70-80{ }^{\circ} \mathrm{C}$ for 12 hours to give a red solution. The volatiles were removed in vacuo to give an orange powder that could be recrystallized from pentane to yield product $(30 \mathrm{mg}, 10 \%) .{ }^{1} \mathrm{H}$ NMR $\left(\mathrm{C}_{6} \mathrm{D}_{6}\right) \delta 7.19(\mathrm{~s}, 12 \mathrm{H}), 7.11\left(\mathrm{~d}, \mathrm{~J}_{\mathrm{HH}}=1.2\right.$ $\mathrm{Hz}, 6 \mathrm{H}$ ), 6.78 (br t, 3H), 3.79 (br t, 6H), 3.18 (sept, $\mathrm{J}_{\mathrm{HH}}=6.7 \mathrm{~Hz}, 12 \mathrm{H}$ ), 2.91 (sept, $\mathrm{J}_{\mathrm{HH}}=6.8$ $\mathrm{Hz}, 6 \mathrm{H}), 2.39(\mathrm{br} \mathrm{t}, 6 \mathrm{H}), 1.36\left(\mathrm{~d}, \mathrm{~J}_{\mathrm{HH}}=6.6 \mathrm{~Hz}, 36 \mathrm{H}\right), 1.20\left(\mathrm{~d}, \mathrm{~J}_{\mathrm{HH}}=6.9 \mathrm{~Hz}, 72 \mathrm{H}\right),-0.12(\mathrm{~s}$, $9 \mathrm{H}) ;{ }^{51} \mathrm{~V}$ NMR $\left(\mathrm{C}_{6} \mathrm{D}_{6}\right) \delta-276$ (br s); UV/Vis $\lambda_{\max }(\mathrm{nm}), \varepsilon\left(\mathrm{M}^{-1} \cdot \mathrm{cm}^{-1}\right)$ : heptane (262 (sh), 3. $\left.\times 10^{4} ; 304,1.3 \times 10^{4} ; 368,1.0 \times 10^{4} ; 456,1.2 \times 10^{4}\right)$. Anal. Calcd for $\mathrm{C}_{117} \mathrm{H}_{168} \mathrm{~N}_{5} \mathrm{SiV}: \mathrm{C}$, 81.52; H, 9.83; N, 4.06. Found: C, 81.61; H, 9.88; N, 4.05. 
[HIPTN ${ }_{3}$ N]V=S- HIPTN $_{3} \mathrm{~N}$ ]V(THF) $(1.00 \mathrm{~g}, 0.59 \mathrm{mmol})$ was added to a $100 \mathrm{~mL}$ solvent bomb type flask and dissolved in pentane. While stirring the solution, $\mathrm{S}_{8}(19 \mathrm{mg}, 74 \mu \mathrm{mol})$ was added. Within minutes the solution turned dark green. Stirring was continued for 12 hours, but no further color change was observed. The reaction mixture was filtered through celite and concentrated in vacuo. Crystallization of the crude product from pentane at $-35^{\circ} \mathrm{C}$ yielded a microcrystalline green product (751 mg, $77 \%):{ }^{1} \mathrm{H}$ NMR $\left(\mathrm{C}_{6} \mathrm{D}_{6}\right) \delta 7.42(\mathrm{br} \mathrm{s}, 6 \mathrm{H}), 7.21(\mathrm{~s}$, $12 \mathrm{H}), 6.48\left(\mathrm{t}, \mathrm{J}_{\mathrm{HH}}=1.3 \mathrm{~Hz}, 3 \mathrm{H}\right), 3.73(\mathrm{brt}, 6 \mathrm{H}), 3.10\left(\mathrm{sept}, \mathrm{J}_{\mathrm{HH}}=6.8 \mathrm{~Hz}, 12 \mathrm{H}\right), 2.92$ (sept, $\left.\mathrm{J}_{\mathrm{HH}}=6.9 \mathrm{~Hz}, 6 \mathrm{H}\right), 1.70\left(\mathrm{t}, \mathrm{J}_{\mathrm{HH}}=5.0 \mathrm{~Hz}, 6 \mathrm{H}\right), 1.35\left(\mathrm{~d}, \mathrm{~J}_{\mathrm{HH}}=6.9 \mathrm{~Hz}, 36 \mathrm{H}\right), 1.24\left(\mathrm{~d}, \mathrm{~J}_{\mathrm{HH}}=6.9\right.$ $\mathrm{Hz}, 36 \mathrm{H}), 1.11\left(\mathrm{br} \mathrm{d}, \mathrm{J}_{\mathrm{HH}}=6.3 \mathrm{~Hz}, 36 \mathrm{H}\right) ;{ }^{51} \mathrm{~V}$ NMR $\left(\mathrm{C}_{6} \mathrm{D}_{6}\right) \delta 755.93(\mathrm{~s})$; UV/Vis $\lambda_{\max }(\mathrm{nm})$, $\varepsilon\left(\mathrm{M}^{-1} \cdot \mathrm{cm}^{-1}\right)$ : heptane $\left(260,4.0 \times 10^{4} ; 296,1.2 \times 10^{4} ; 354,1.2 \times 10^{4} ; 414,1.5 \times 10^{4} ; 606,8.0\right.$ $\times 10^{4}$ ). Anal. Calcd for $\mathrm{C}_{114} \mathrm{H}_{159} \mathrm{~N}_{4} \mathrm{SV}$ : C, 82.06; H, 9.61; N, 3.36; S, 1.92. Found: C, 82.15; H, 9.48; N, 3.31; S, 1.97 .

[HIPTN ${ }_{3}$ N]V=O- $\left[\mathrm{HIPTN}_{3} \mathrm{~N}\right.$ ]V(THF) $(300 \mathrm{mg}, 0.18 \mathrm{mmol})$ was added to a $25 \mathrm{~mL}$ solvent bomb type flask with a Teflon valve, to which was added $\sim 15 \mathrm{~mL}$ of toluene. While the solution was stirring, propylene oxide $(25 \mu \mathrm{L}, 0.34 \mathrm{mmol})$ was added, resulting in an immediate color change to black-violet. The reaction mixture was heated at $c a .80^{\circ} \mathrm{C}$ for 16 hours and the solvent was removed on a vacuum line. The solid residue was dissolved in pentane and the solution was filtered through Celite. Crystallization from a supersaturated pentane solution at ca. $-40{ }^{\circ} \mathrm{C}$ yielded $\left[\mathrm{HIPTN} \mathrm{N}_{3} \mathrm{~N}\right] \mathrm{V}=\mathrm{O}$ as a purple powder $(198 \mathrm{mg}, 68 \%) .{ }^{1} \mathrm{H} \mathrm{NMR}\left(\mathrm{C}_{6} \mathrm{D}_{6}\right) \delta$ 7.78 (br s, 6H), $7.20(\mathrm{~s}, 12 \mathrm{H}), 6.51(\mathrm{~s}, 3 \mathrm{H}), 3.69$ (br s, 6H), 3.08 (sept, $\left.\mathrm{J}_{\mathrm{HH}}=6.7 \mathrm{~Hz}, 12 \mathrm{H}\right)$, $2.93\left(\mathrm{sept}, \mathrm{J}_{\mathrm{HH}}=6.9 \mathrm{~Hz}, 6 \mathrm{H}\right), 1.98(\mathrm{br} \mathrm{s}, 6 \mathrm{H}), 1.36\left(\mathrm{~d}, \mathrm{~J}_{\mathrm{HH}}=6.9 \mathrm{~Hz}, 36 \mathrm{H}\right), 1.21\left(\mathrm{~d}, \mathrm{~J}_{\mathrm{HH}}=6.8\right.$ $\mathrm{Hz}, 36 \mathrm{H}), 1.07$ (br s, $36 \mathrm{H}) ;{ }^{51} \mathrm{~V}$ NMR $\left(\mathrm{C}_{6} \mathrm{D}_{6}\right) \delta-115(\mathrm{~s}) ; \mathrm{UV} / \mathrm{Vis} \lambda_{\max }(\mathrm{nm}), \varepsilon\left(\mathrm{M}^{-1} \cdot \mathrm{cm}^{-1}\right)$ : heptane (264 (sh), $\left.2.4 \times 10^{4} ; 288(\mathrm{sh}), 1.7 \times 10^{4} ; 412,1.6 \times 10^{4} ; 542,1.5 \times 10^{4}\right)$. Anal. Calcd for $\mathrm{C}_{114} \mathrm{H}_{159} \mathrm{~N}_{4} \mathrm{OV}$ : C, 82.85; H, 9.70; N, 3.39. Found: C, 82.75; H, 9.63; N, 3.35 .

Observation of [HIPTN $\left.{ }_{3} \mathrm{~N}\right] \mathbf{V}(\mathrm{CO})$-A sample of [HIPTN $\left.{ }_{3} \mathrm{~N}\right] \mathrm{V}$ (THF) $(50 \mathrm{mg}, 29 \mu \mathrm{mol})$ was added to a $25 \mathrm{~mL}$ solvent bomb type flask with a Teflon valve and was dissolved in $c a$. 6-7 mL of pentane. The resulting green solution was degassed once (freeze-pump-thaw) and exposed to $1 \mathrm{~atm}$. of CO. In $c a .5$ minutes the solution turned red-gold and was allowed to stir for another 30 minutes. The volatiles were then removed in vacuo and the resulting residue was taken up in $c a .1 \mathrm{~mL}$ of heptane and used for IR analysis directly. IR(heptane) $\mathrm{cm}^{-1} 2076$ $\left(v_{\mathrm{CO}}\right)$.

Observation of [HIPTN $\left.{ }_{3} \mathrm{~N}\right] \mathbf{V}\left({ }^{13} \mathrm{CO}\right)$-A sample of [HIPTN $\left.{ }_{3} \mathrm{~N}\right] \mathrm{V}$ (THF) $(50 \mathrm{mg}, 29 \mu \mathrm{mol})$ was added to a $25 \mathrm{~mL}$ solvent bomb type flask with a Teflon valve and was dissolved in $c a$. 6-7 mL of pentane. The resulting green solution was degassed once (freeze-pump-thaw) and exposed to $1 \mathrm{~atm}$. of CO. In $c a .5$ minutes the solution turned red-gold and was allowed to stir for another 30 minutes. The volatiles were then removed in vacuo and the resulting residue was taken up in $c a .1 \mathrm{~mL}$ of heptane and used for IR analysis directly. IR(heptane) $\mathrm{cm}^{-1} 2030$ $\left(v_{\mathrm{CO}},{ }^{13} \mathrm{CO}\right), 1980\left(v_{\mathrm{CO}},{ }^{13} \mathrm{C}^{18} \mathrm{O}\right)$.

\section{Supplementary Material}

Refer to Web version on PubMed Central for supplementary material.

\section{Acknowledgements}

R.R.S. is grateful to the National Institutes of Health (GM 31978) for research support. 


\section{References}

1. (a) Schrock RR. Acc Chem Res 1997;30:9. (b) Greco GE, Schrock RR. Inorg Chem 2001;40:3850. [PubMed: 11466042] (c) Greco GE, Schrock RR. Inorg Chem 2001;40:3861. [PubMed: 11466043]

2. Schrock RR. Acc Chem Res 2005;38:955. [PubMed: 16359167]

3. (a) Yandulov DV, Schrock RR. J Am Chem Soc 2002;124:6252. [PubMed: 12033849] (b) Yandulov DV, Schrock RR, Rheingold AL, Ceccarelli C, Davis WM. Inorg Chem 2003;42:796. [PubMed: 12562193] (c) Yandulov DV, Schrock RR. Science 2003;301:76. [PubMed: 12843387] (d) Weare WW, Dai C, Byrnes MJ, Chin J, Schrock RR. Proc Nat Acad Sci. in press (e) Yandulov DV, Schrock RR. Inorg Chem 2005;44:1103. [PubMed: 15859292] (f) Weare WW, Schrock RR, Hock AS, Müller P. Inorg Chem. in press

4. Yandulov DV, Schrock RR. Canad J Chem 2005;83:341.

5. Smythe NC, Schrock RR, Müller P, Weare WW. Inorg Chem 2006;45:7111-7118. [PubMed: 16933911]

6. (a) Burgess BK, Lowe DJ. Chem Rev 1996;96:2983. [PubMed: 11848849]Hardy, RWF.; Bottomley, F.; Burns, RC. A Treatise on Dinitrogen Fixation. Wiley-Interscience; New York: 1979. Veeger, C.; Newton, WE. Advances in Nitrogen Fixation Research. Dr. W. Junk/Martinus Nijhoff; Boston: 1984. Coughlan, MP., editor. Molybdenum and Molybdenum-containing Enzymes. Pergamon; New York: 1980.

7. (a) Eady RR. Chem Rev 1996;96:3013. [PubMed: 11848850] (b) Smith BE. Adv Inorg Chem 1999;47:159-218. (c) Rehder D. Coord Chem Rev 1999;182:297.

8. (a) Kim J, Rees DC. Science 1992;257:1677. [PubMed: 1529354] (b) Bolin JT, Ronco AE, Morgan TV, Mortenson LE, Xuong LE. Proc Nat Acad Sci 1993;90:1078. [PubMed: 8430077] (c) Rees DC, Howard JB. Curr Opinion Chem Biol 2000;4:559. (d) Einsle O, Tezcan FA, Andrade SLA, Schmid B, Yoshida M, Howard JB, Rees DC. Science 2002;297:1696. [PubMed: 12215645]

9. (a) Ferguson R, Solari E, Floriani C, Osella D, Ravera M, Re N, Chiesi-Villa A, Rizzoli C. J Am Chem Soc 1997;119:10104. (b) Buijink JKF, Meetsma A, Teuben JH. Organometallics 1993;12:2004. (c) Song J, Berno P, Gambarotta S. J Am Chem Soc 1994;116:6927. (d) Desmangles N, Jenkins H, Ruppa KB, Gambarotta S. Inorg Chim Acta 1996;250:1. (e) Ferguson R, Solari E, Floriani C, Chiesi-Villa A, Rizzoli C. Angew Chem, Int Ed Engl 1993;32:396.

10. (a) Vidyaratne I, Gambarotta S, Korobkov I, Budzelaar PHM. Inorg Chem 2005;44:1187. [PubMed: 15732953] (b) Edema JJH, Meetsma A, Gambarotta S. J Am Chem Soc 1989;111:6878. (c) Berno P, Hao S, Minhas R, Gambarotta S. J Am Chem Soc 1994;116:7417.

11. (a) Gailus H, Woitha C, Rehder D. J Chem Soc, Dalton Trans 1994:3471. (b) Rehder D, Woitha C, Priebsch W, Gailus H. J Chem Soc, Chem Commun 1992:364. (c) Woitha C, Rehder D. Angew Chem Int Ed Engl 1990;102:1438.

12. (a) Chatt J, Dilworth JR, Richards RL. Chem Rev 1978;78:589. (b) Hidai M. Coord Chem Rev 1999;185-186:99.

13. (a) Turner HW, Fellmann JD, Rocklage SM, Schrock RR, Churchill MR, Wasserman HJ. J Am Chem Soc 1980;102:7809. (b) Rocklage SM, Turner HW, Fellmann JD, Schrock RR. Organometallics 1982;1:703. (c) Rocklage SM, Schrock RR. J Am Chem Soc 1982;104:3077.

14. Plass W, Verkade JG. J Am Chem Soc 1992;114:2275.

15. (a) Nomura K, Schrock RR, Davis WM. Inorg Chem 1996;35:3695. (b) Rosenberger C, Schrock RR, Davis WM. Inorg Chem 1997;36:123.

16. (a) Cummins CC, Schrock RR, Davis WM. Organometallics 1992;11:1452. (b) Cummins CC, Schrock RR, Davis WM. Inorg Chem 1994;33:1448.

17. Cummins CC, Lee J, Schrock RR, Davis WM. Angew Chem, Int Ed Engl 1992;31:1501.

18. (a) Clentsmith GKB, Bates VME, Hitchcock PB, Cloke FGN. Journal of the American Chemical Society 1999;121(44):10444. (b) Studt F, Lamarche Vanessa ME, Clentsmith Guy KB, Cloke FGN, Tuczek F. Dalton Trans 2005:1052. [PubMed: 15739007]

19. Hayton TW, Daff PJ, Legzdins P, Rettig SJ, Patric BO. Inorg Chem 2002;41:4114. [PubMed: 12160398]

20. Song JI, Gambarotta S. Chem Eur J 1996;2:1258.

21. Brask JK, Dura-Vila V, Diaconescu PL, Cummins CC. Chem Commun 2002:902. 
22. (a) Manzer LE. Inorg Syn 1982;21:135. (b) Hawker PN, Timms PL. J Chem Soc, Dalton Trans 1983:1123.

23. Schrock RR, Sturgeoff LG, Sharp PR. Inorg Chem 1983;22:2801.

24. Moss RA, Terpinski J, Cox DP, Denney DZ, Krogh-Jespersen K. J Am Chem Soc 1985;107:2743.

25. Evans DF. J Chem Soc 1959:2003.

26. Sur SK. J Mag Res 1989;82:169.

27. Sheldrick GM. Acta Cryst Sect A 1990;46:467.

28. Sheldrick, GM. SHELXL 97. Universität Göttingen; Göttingen, Germany: 1997.

29. Farrugia LJ. J Appl Cryst 1997;30:565. 


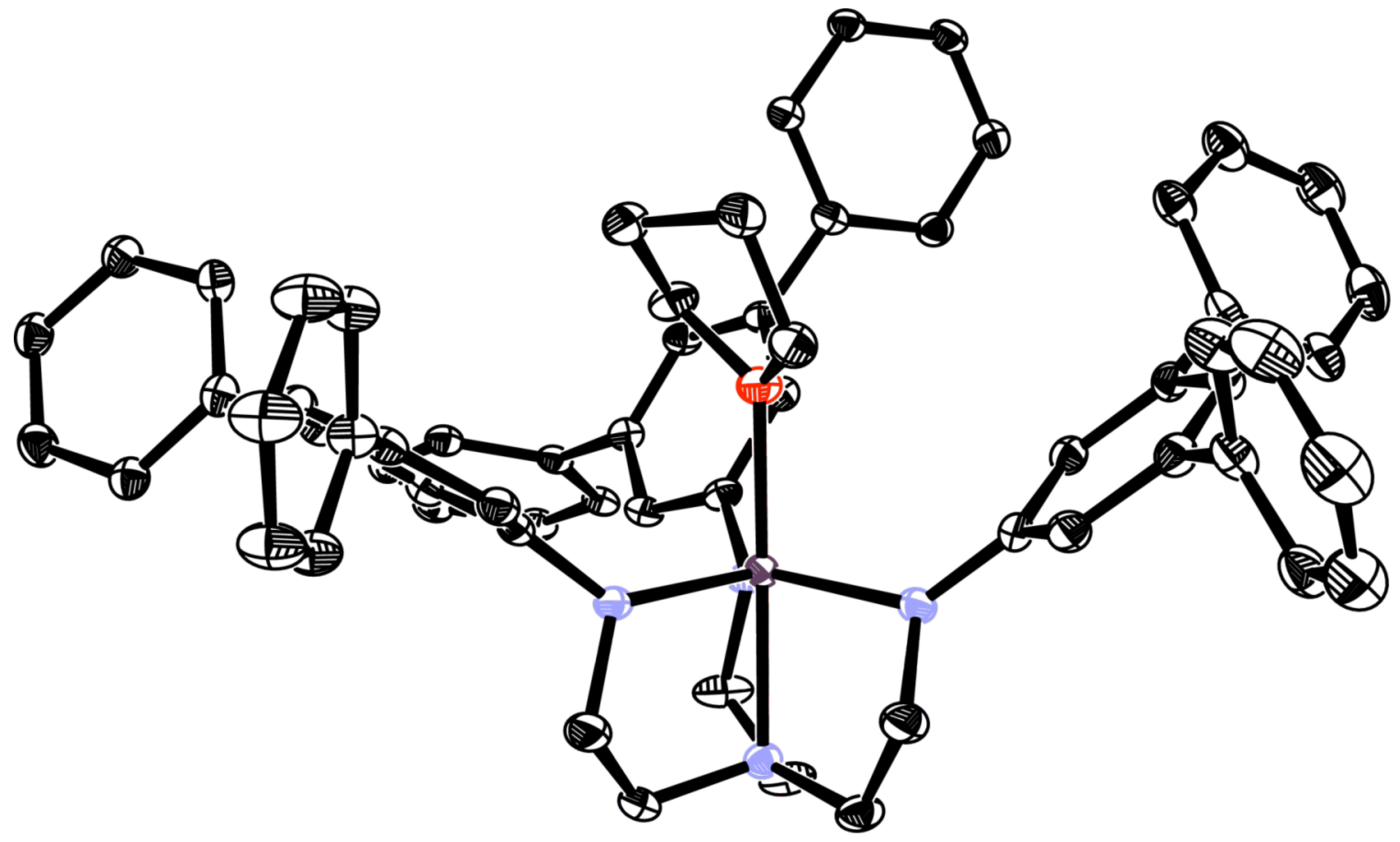

Figure 1.

Thermal ellipsoid drawing of [HIPTN $\left.{ }_{3} \mathrm{~N}\right] \mathrm{V}$ (THF) (ellipsoids at $50 \%$ probability) with isopropyl groups and hydrogen atoms removed for clarity. 


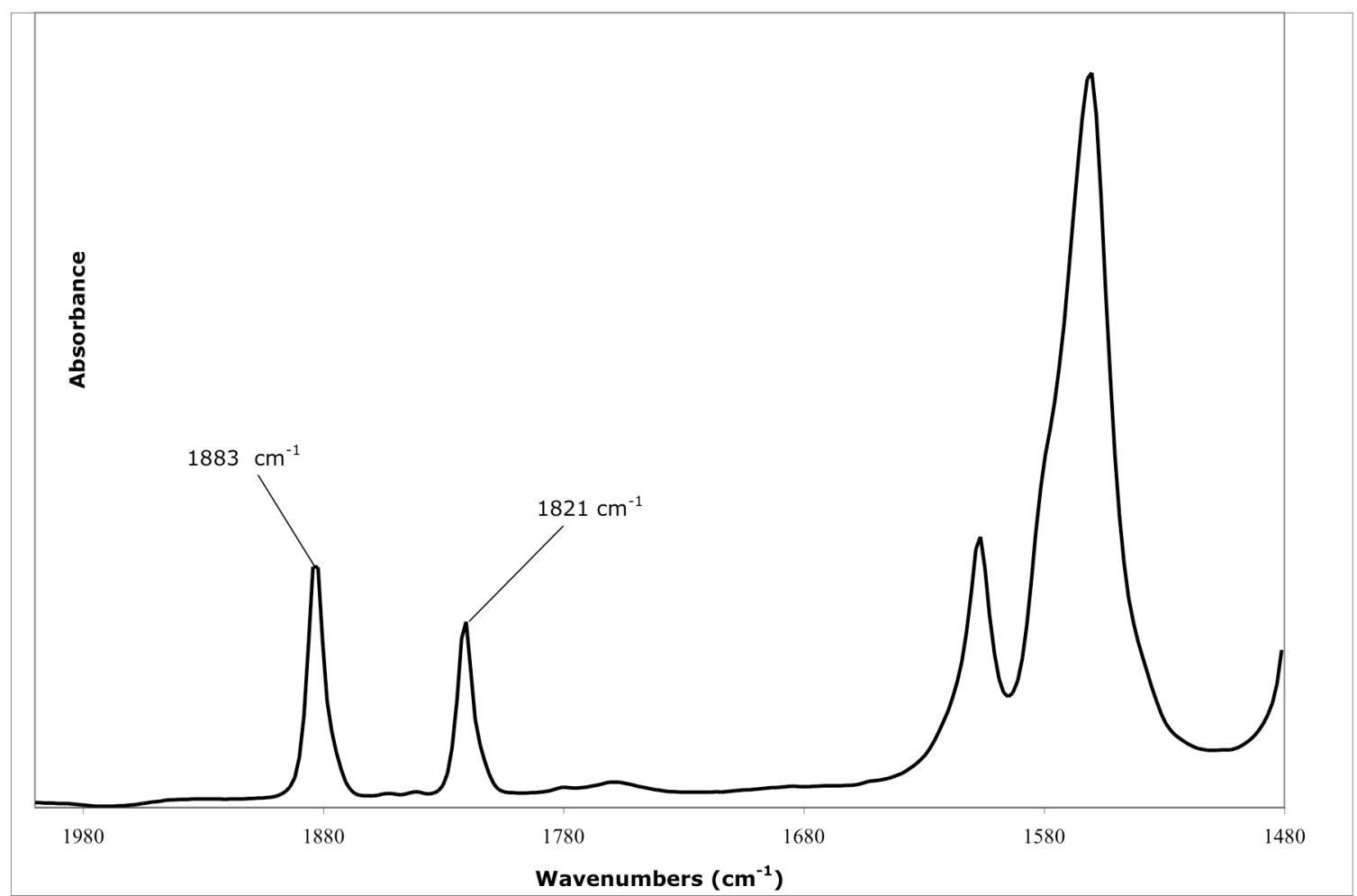

Figure 2.

Solution IR spectrum of $\left\{\left[\mathrm{HIPTN} \mathrm{N}_{3} \mathrm{NV}^{15} \mathrm{~N}_{2}\right\} \mathrm{K}\right.$ in THF (subtracted) under dinitrogen showing a mixture that contains $\left\{\left[\mathrm{HIPTN} \mathrm{N}_{3} \mathrm{~N}^{14} \mathrm{~V}_{2}\right\} \mathrm{K}\right.$ as a consequence of ready exchange. 


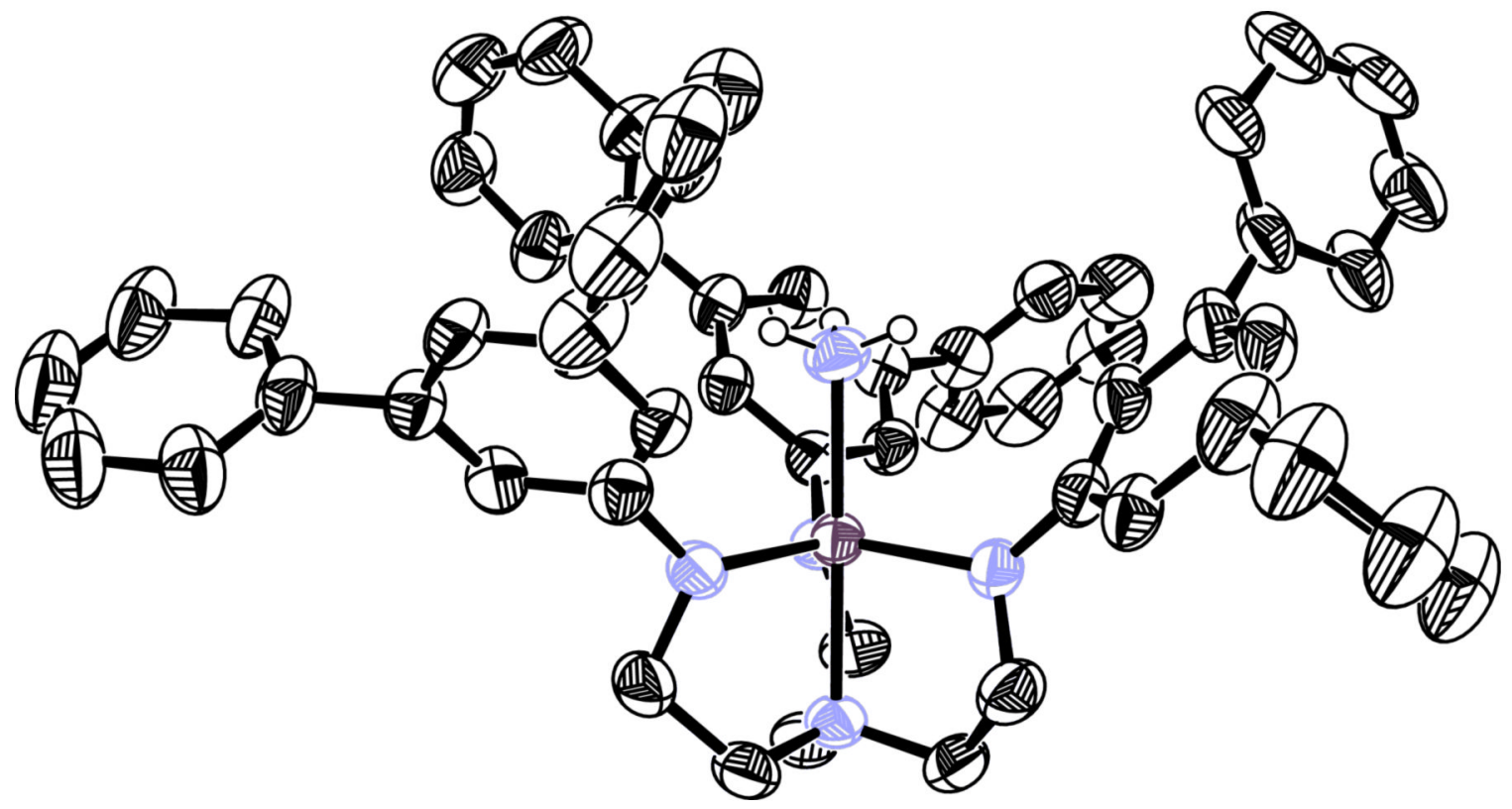

Figure 3.

Thermal ellipsoid drawing of $\left[\mathrm{HIPTN}_{3} \mathrm{~N}\right] \mathrm{V}\left(\mathrm{NH}_{3}\right)$ (ellipsoids at $50 \%$ probability) with isopropyl groups and non-ammonia hydrogen atoms removed for clarity. 


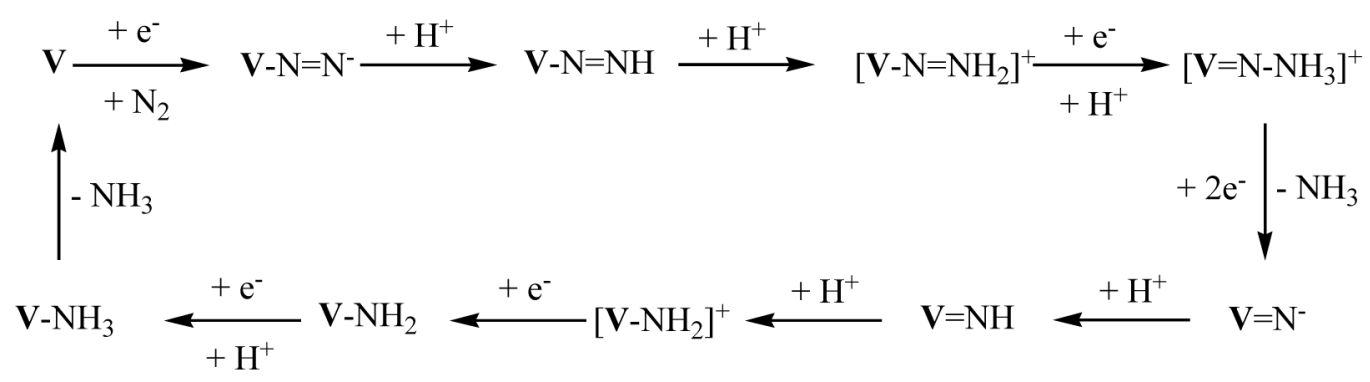

Scheme 1.

A plausible mechanism for the reduction of dinitrogen to ammonia in the [HIPTN $\left.{ }_{3} \mathrm{~N}\right] \mathrm{V}$ system. 


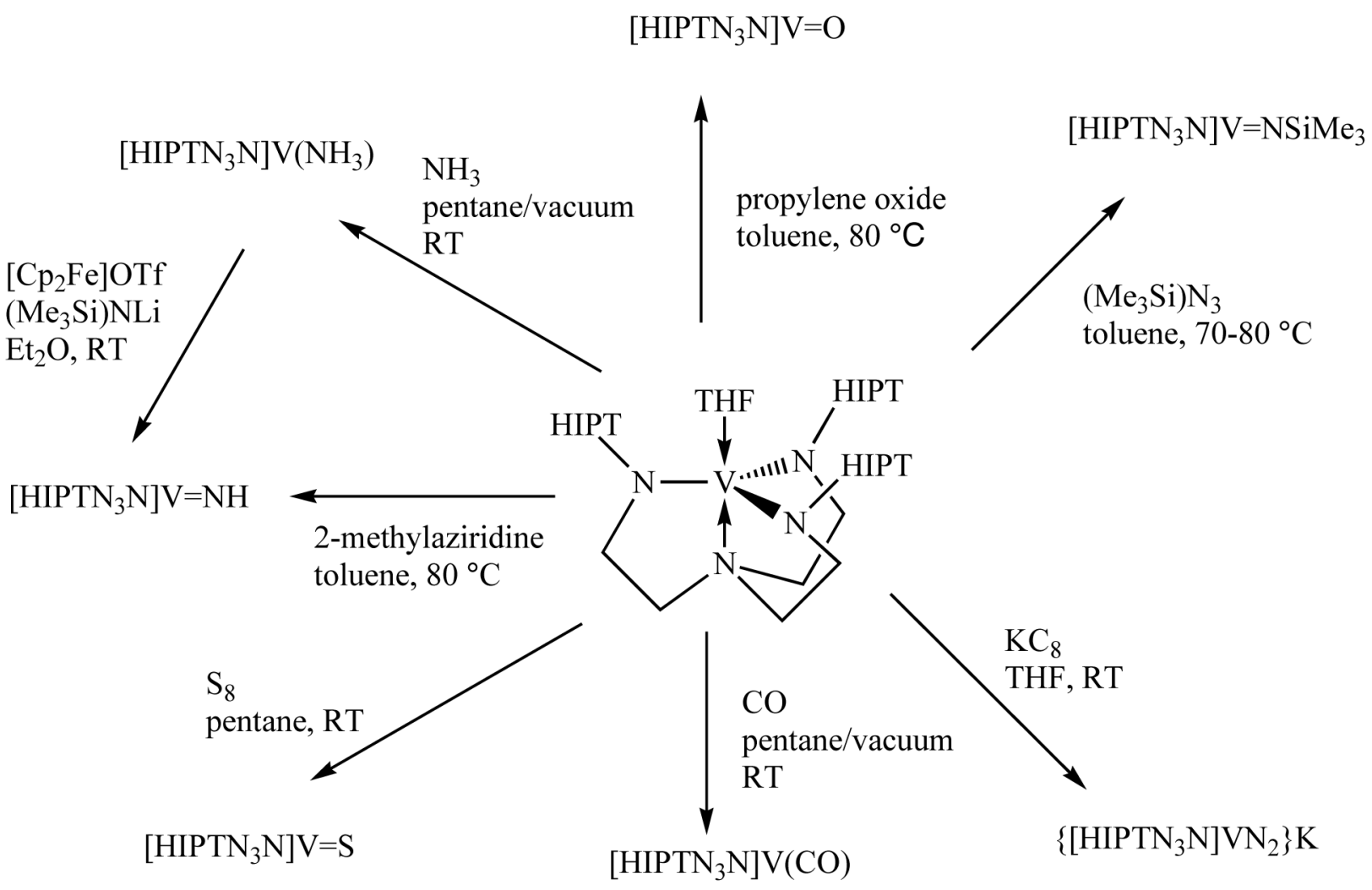

Scheme 2.

Reactions of [HIPTN $\left.{ }_{3} \mathrm{~N}\right] \mathrm{V}(\mathrm{THF})$ 
Table 1

Crystal data and structure refinement for $\left[\mathrm{HIPTN}{ }_{3} \mathrm{~N}\right] \mathrm{V}(\mathrm{THF})$ and $\left[\mathrm{HIPTN}_{3} \mathrm{~N}\right] \mathrm{V}\left(\mathrm{NH}_{3}\right)$.

\begin{tabular}{|c|c|c|}
\hline & {$\left[\right.$ HIPTN $_{3}$ N]V(THF) } & {$\left[\mathrm{HIPTN}_{3} \mathrm{~N}\right] \mathrm{V}\left(\mathrm{NH}_{3}\right)$} \\
\hline $\begin{array}{l}\text { Empirical formula } \\
\text { Formula weight } \\
\text { Temperature } \\
\text { Crystal system } \\
\text { Space group } \\
\text { Unit cell dimensions } \\
\\
\text { Volume } \\
Z \\
\text { Density (calculated) } \\
\text { Absorption coefficient } \\
\text { F(000) } \\
\text { Crystal size } \\
\text { Theta range for data collection } \\
\text { Index ranges } \\
\text { Reflections collected } \\
\text { Independent reflections } \\
\text { Completeness to theta }=\left(x^{\circ}\right) \\
\text { Max. and min. transmission } \\
\text { Data/restraints/parameters } \\
\text { Goodness-of-fit on } \mathrm{F}^{2} \\
\text { Final R indices [I }>2 \text { sigma(I)] } \\
\text { R indices (all data) } \\
\text { Largest diff. peak and hole }\end{array}$ & $\begin{array}{l}\mathrm{C}_{132} \mathrm{H}_{199} \mathrm{~N}_{4} \mathrm{OV} \\
1908.89 \\
100(2) \mathrm{K} \\
\text { Triclinic } \\
\mathrm{P} 1 \\
\mathrm{a}=17.7727(6) \AA \\
\mathrm{b}=18.3700(7) \AA \\
\mathrm{c}=21.2032(9) \AA \\
\mathrm{a}=113.9930(10)^{\circ} \\
\mathrm{b}=99.8920(10)^{\circ} \\
\mathrm{g}=96.5660(10)^{\circ} \\
6098.5(4) \AA^{3} \\
2 \\
1.040 \mathrm{Mg} / \mathrm{m}^{3} \\
0.130 \mathrm{~mm} \\
2100 \\
0.20 \times 0.20 \times 0.08 \mathrm{~mm}^{3} \\
1.40 \text { to } 28.28^{\circ} \\
-23<=\mathrm{h}<=23 \\
-24<=\mathrm{k}<=24 \\
-28<=1<=27 \\
127420 \\
30238[\mathrm{R}(\mathrm{int})=0.0638] \\
99.9 \%(28.28) \\
0.9897 \text { and } 0.9745 \\
30238 / 397 / 1243 \\
1.043 \\
\mathrm{R} 1=0.0696, \mathrm{wR} 2=0.1764 \\
\mathrm{R} 1=0.1069, \mathrm{wR} 2=0.2005 \\
0.896 \text { and }-0.562 \mathrm{e} . \AA^{-3}\end{array}$ & $\begin{array}{l}\mathrm{C}_{121} \mathrm{H}_{178} \mathrm{~N}_{5} \mathrm{~V} \\
1753.62 \\
193(2) \mathrm{K} \\
\text { Monoclinic } \\
\mathrm{Cc} \\
\mathrm{a}=16.1153(4) \AA \\
\mathrm{b}=39.7548(11) \AA \\
\mathrm{c}=18.0197(5) \AA \\
\mathrm{a}=90^{\circ} \\
\mathrm{b}=93.0540(10)^{\circ} \\
\mathrm{g}=90^{\circ} \\
11528.1(5) \AA^{3} \\
4 \\
1.010 \mathrm{Mg} / \mathrm{m}^{3} \\
0.132 \mathrm{~mm} \\
3848 \\
0.20 \times 0.17 \times 0.10 \mathrm{~mm}^{3} \\
1.99 \text { to } 25.03^{\circ} \\
-18<=\mathrm{h}<=19 \\
-47<=\mathrm{k}<=41 \\
-21<=1<=13 \\
29563 \\
15469[\mathrm{R}(\mathrm{int})=0.0305] \\
99.9 \%(25.03) \\
0.9869 \text { and } 0.9741 \\
15469 / 3023 / 1536 \\
1.015 \\
\mathrm{R} 1=0.0584, \mathrm{wR} 2=0.1452 \\
\mathrm{R} 1=0.0766, \mathrm{wR} 2=0.1585 \\
0.317 \text { and }-0.268 \mathrm{e} . \AA^{-3}\end{array}$ \\
\hline
\end{tabular}

${ }^{a}$ In all cases the wavelength was $0.71073 \AA$, the absorption correction was semi-empirical from equivalents, and the refinement method was full-matrix least-squares on $\mathrm{F}^{2}$. 
Table 2

Principle Bond Distances and Angles in $\left[\mathrm{HIPTN}_{3} \mathrm{~N}\right] \mathrm{V}(\mathrm{THF})$ and $\left[\mathrm{HIPTN}_{3} \mathrm{~N}\right] \mathrm{V}\left(\mathrm{NH}_{3}\right)$.

\begin{tabular}{lll}
\hline & {$\left[\mathbf{H I P T N}_{\mathbf{3}} \mathbf{N}\right] \mathbf{V}(\mathbf{T H F})$} & {$\left[\mathbf{H I P T N}_{\mathbf{3}} \mathbf{N}\right]_{\mathbf{V}}\left(\mathbf{N H}_{\mathbf{3}}\right)$} \\
\hline V-N(1) & & $1.9555(8)$ \\
V-N(2) & $1.9760(17)$ & $1.9576(7)$ \\
V-N(3) & $1.9675(18)$ & $1.9520(8)$ \\
V-N(4) & $1.9173(18)$ & $2.1486(7)$ \\
V-X & $2.1627(18)$ & $2.1623(8)$ \\
N(1)-V-N(2) & $2.1399(15)$ & $118.19(3)$ \\
N(1)-V-N(3) & $123.82(8)$ & $118.67(3)$ \\
N(2)-V-N(3) & $114.39(8)$ & $118.43(3)$ \\
N(1)-V-N(4) & $115.95(8)$ & $82.33(3)$ \\
N(1)-V-X & $81.06(7)$ & $97.57(3)$ \\
N(2)-V-N(4) & $94.94(7)$ & $82.90(3)$ \\
N(2)-V-X & $82.72(7)$ & $97.63(3)$ \\
N(3)-V-N(4) & $105.76(7)$ & $82.99(3)$ \\
N(3)-V-X & $82.00(7)$ & $96.57(3)$ \\
N(4)-V-X & $92.87(7)$ & $179.43(3)$ \\
X-V-N(1)-C & $171.42(6)$ & $1.45(8)$ \\
X-V-N(2)-C & $-20.4(2)$ & $4.55(9)$ \\
X-V-N(3)-C & $-10.5(2)$ & $0.17(8)$ \\
& $-15.3(2)$ & \\
\hline
\end{tabular}


Table 3

${ }^{51} \mathrm{~V}$ NMR shifts $\left(\mathrm{C}_{6} \mathrm{D}_{6}\right)$ of analogous $\left[\mathrm{Me}_{3} \mathrm{SiN}_{3} \mathrm{~N}\right] \mathrm{V}$ and $\left[\mathrm{HIPTN}_{3} \mathrm{~N}\right] \mathrm{V}$ complexes.

\begin{tabular}{|c|c|c|}
\hline & {$\left[\mathbf{M e}_{3} \mathbf{S i N}_{3} \mathbf{N}\right]^{3-}$ ligand } & {$\left[\mathbf{H I P T N}_{3} \mathbf{N}\right]^{3-}$ ligand } \\
\hline $\mathrm{V}=\mathrm{S}$ & $621 \mathrm{ppm}$ & $756 \mathrm{ppm}$ \\
\hline $\mathrm{Y}$ & $252 \mathrm{ppm}$ & $-334 \mathrm{ppm}$ \\
\hline $\mathrm{V}=\mathrm{NH}$ & $\sim-80 \mathrm{ppm}$ & $-276 \mathrm{ppm}$ \\
\hline $\mathrm{V}=\mathrm{N}\left(\mathrm{SiMe}_{3}\right)$ & $-173 \mathrm{ppm}$ & $-115 \mathrm{ppm}$ \\
\hline $\mathrm{V}=\mathrm{O}$ & &
\end{tabular}

